\title{
Managing Shipping Companies, the Way Their Pioneers Did: The Case-Studies of Aristotelis S. Onassis II and Angeliki Frangou
}

\author{
Alexandros M. Goulielmos ${ }^{1,2}$ \\ ${ }^{1}$ Former Professor of Marine Economics, Faculty of Maritime and Industrial Studies, Department of Maritime Studies, \\ University of Piraeus, Piraeus, Greece \\ ${ }^{2}$ Shipping, Transport and Logistics Department, Business College of Athens, Athens, Greece \\ Email: ag@unipi.gr, am.goulielmos@hotmail.com, agoulielmos@bca.edu.gr
}

How to cite this paper: Goulielmos, A. M. (2021). Managing Shipping Companies, the Way Their Pioneers Did: The Case-Studies of Aristotelis S. Onassis II and Angeliki Frangou. Modern Economy, 12, 247-273. https://doi.org/10.4236/me.2021.121013

Received: December 10, 2020

Accepted: January 26, 2021

Published: January 29, 2021

Copyright ( 2021 by author(s) and Scientific Research Publishing Inc. This work is licensed under the Creative Commons Attribution International License (CC BY 4.0).

http://creativecommons.org/licenses/by/4.0/ (c) (i) Open Access

\begin{abstract}
This work finalized the presentation of the business life of the late (golden) Greek shipowner Aristotelis S. Onassis, which we started in a previous paper (in this journal ${ }^{1}$ ). Our purpose was to provide a real example, in which prospective managers may find-out certain strong points. Onassis believed in his arithmetic as far as shipping economies of scale are concerned and in the future of oil consumption, since 1938. The largest tanker in the water was always his, a fixed target. He was also after a rapid growth of his fleet, using other people's money. He was building almost 3 ships each year on average for about 4 continuous decades! The top Chian shipowner Mrs. Angeliki N. Frangou, reached a fleet of over $18 \mathrm{~m}$ dwt-3 times larger than that of Onassis! She is strong knowing capital markets, as she used to work in Wall Street, and she has the ability to derive the funds she needs at low interest rates. She (a mechanical Engineer by education) understands also the "cost minimization" principle. She was round during the end-2008 global financial crisis, when she learned that a hundred of opportunities crop-up during such a time, provided one has funds. Unlike Onassis, she was on board her father ships since a little girl, and surely tradition, (and her conservative father), taught her the old shipping wisdom... while the modern one, she learned by herself. The method used was to read a great number of books, articles, announcements and interviews, many more than those mentioned in the reference list. To note-down the business style of each shipowner, dropping-out all irrelevant facts and private life. For Onassis, we read more than 10 books. Our scientific curiosity and our experience as a professor of shipping management enabled
\end{abstract}

1"Managing shipping companies, the way their pioneers did: the case-studies of vafias $\mathrm{N}$ family and Aristotelis S. Onassis". 
us to single out the management ways and the principles applied by these two managers. The end purpose was to teach readers of how shipping business can be carried-out with success given the changes occurred.

\section{Keywords}

A Case-Study Related to Aristotelis S. Onassis, also to Angeliki Frangou, Liberty Ships, Onassis' Animal Spirits

\section{Introduction}

It has been written ${ }^{2}$ that Greek shipowners are of 2 at least types (Graph 1).

The traditionalists are those with long-established names, who were enduring for several generations, and at least five. They usually originate from 1 family and 1 island with a seafaring tradition, such as Andros and Chios, prior to 1800s. These companies are usually characterized by a slow and steady growth. An example is the late Stavros Livanos ${ }^{3}$. The Parachutists are those, a first-generation owner, with no particular background in shipping, who suddenly landed on maritime...sea, during the years following the $2^{\text {nd }}$ World War.

The traditionalists were endowed by the 107 surplus ships for Liberty (presented below), available (lend-lease) at low prices in 1946 by USA Government to Greek shipowners. The Parachutists had a sudden and fast growth. One strong example is Onassis. In Greece, ship owning is a way of life, and not only a profession, and prior knowhow is not a necessary condition to become a shipowner. Best example is the "Martinos family" (1969), belonging rather to Parachutists. It created 3 top shipping companies ${ }^{4}$ one for each brother- and a

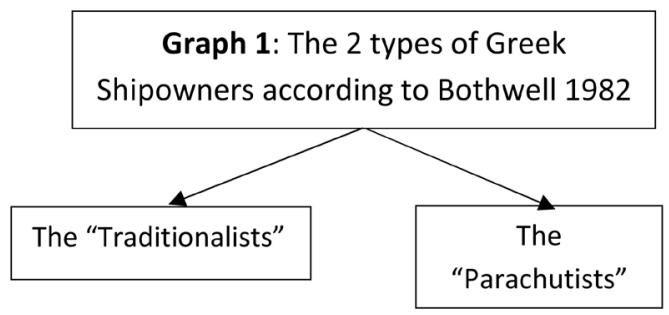

Graph 1. The 2 types of greek Shipowners according to Bothwell (1982). Source: author.

${ }^{2}$ Bothwell, J. H. (1982) Com.

${ }^{3} \mathrm{He}$ came from Chios (Kardamyla), born in 1887. He was a Chief Engineer. In 1917 settled-down in London establishing a shipping office. After $2^{\text {nd }}$ World War he owned over 30 vessels of which 9 new-buildings. In 1948 obtained a tanker of 26,000 tons. He passed away in 1956 . He was a lover of money.

${ }^{4}$ Thenamaris; Minerva and Eastern owning about a total of $25 \mathrm{~m}$ dwt in 2018! There is a large number of companies created by non-traditional shipowners emerging after 1960s. As we mentioned elsewhere $1 / 3$ of companies come from ex-sea officers (Captains and Engineers). One third is created by shore industrialists and $1 / 3$ are traditionalists out of 1000 at least shipping companies. We may stress here the importance of the maritime cluster existing in Greece, where one learns the business of shipping, finds crews and many former senior staff of shipping companies create their own shipping company, best example being Costas Priftis, of Thenamaris. 
two-generation company for Thenamaris. This family started with an old, using steam, used ${ }^{5}$ dry cargo ship, and hired experienced departmental/divisional managers till owners learned the business. Tradition is truly a strong motive among Greeks not only in Shipping but also in national issues.

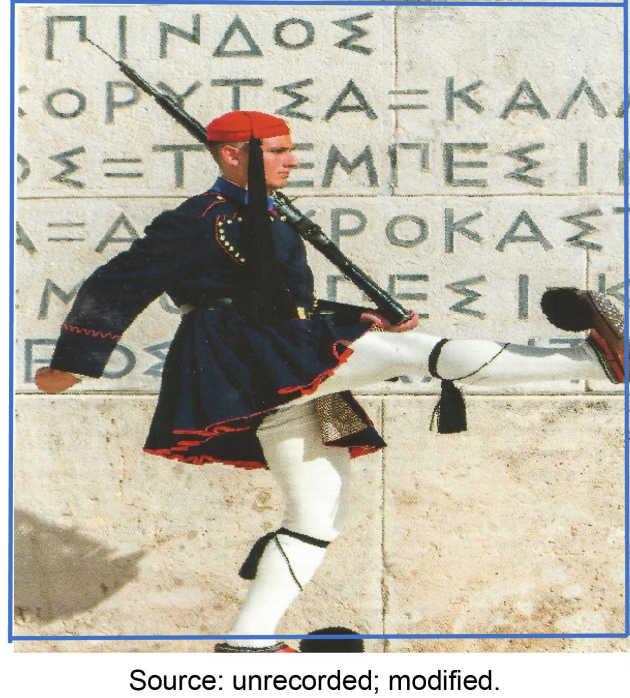

\section{Aim and Organization of Paper}

We will present one of the past and one of the present Greek shipowners as Managers, so that to reveal their management style, behind their fleet, so that to teach present or future managers by their example. The selection has been made so that to have an old and a modern shipowner. This work emanated from the fact that certain shipping managers have built great fortunes and to the students of shipping business there is always the inclination to find-out how and why?

This work is structured and organized in three parts, as follows: Next is a literature review followed by part I dealing with the case-study of the 107 ships built for liberty in 1941-1945. Then is Part II dealing with Onassis business life: a case-study II, followed by part III: the case-study of Mrs. Angeliki N. Frangou. Finally, we conclude.

\section{Literature Review}

Lowry N. $(2003)^{6}$ wrote for Onassis a book. For this paper I had the same idea as Mpatis (1999) had. The idea came to Mpatis during a presentation of a number of bachelor degree essays in the Dept. of Maritime Studies (University of Piraeus) (in 1998). The presentations were overwhelmed by statistics, but there was no reference to the men behind them...Mpatis decided ${ }^{7}$ to write a book to

\footnotetext{
${ }^{5}$ The obstacle to become a shipowner is to find, or have, the own capital in USA\$, most probably a $40 \%$ of the value of a ship. This is a necessary condition. Overaged ships are cheaper and Greeks most frequently than never bought such ships. In old times Greeks gathered the savings of say about 100 persons to buy a ship, till Greeks became rich as nowadays.

${ }^{6}$ I thank the Foundation for sending me one copy.

7"Vision magazine”, Greek shipping Vision; date unknown, pp. 110-112.
} 
show-up the human element! We decided to write a number of papers for the same reason.

Randoy et al. (2003) studied the good corporate governance in maritime firms, empirically testing-among Norwegian and Swedish firms only if the founding family leader-CEO, increases performance, (ROA-return on assets), in shipping, and if board's independence is related to higher performance ${ }^{8}$. We may ask for further research: does shipping companies' fast decision-making provide higher profits, together with perfect timing, when only one single manager does it? Does in decision-making family hierarchy prevail? What conclusion is drawn if we compare the performance of personal companies with family ones?

Stopford M. (2009) mentioned Onassis repeatedly and said that shipping volatility created him (p. 3). Onassis in 1956 earned $\$ 80 \mathrm{~m}$ due to $1^{\text {st }}$ Suez Canal closure, but he was wrong believing that this will last for years (p. 702). His aide Costas Gratsos told him to use the "time charters" and...he, secretly, chartered 12 tankers to Esso for 3 years and 3 months!

Koufopoulos et al. (2010) used a maritime directory, in 2006-7, to study-out the governance structure of the Greek owned companies having more than 5 vessels. This coupled with 179 questionnaires addressed to their managing directors. Twenty-seven responses were received-back only $(\sim 15 \%)$. They found-out (Table 1):

Further research may answer: is the family hierarchy respected during control (?) and what happens if managers are e.g., two or 3 (of equal standing) brothers? Interesting is also what happens if there are disagreements between father and son, and between brother and brother ${ }^{9}$ ?

Pedagogical is the case of the ex-Greek company "Stelmar Shipping Co Ltd"

Table 1. Greek owners with more than 5 vessels \& their governance structure (2006-2007).

\begin{tabular}{llll}
\hline $\begin{array}{l}\text { Family is: owner } \\
\text { and manager }\end{array}$ & $\begin{array}{l}\text { The founding (family) } \\
\text { member is the leader }\end{array}$ & $\begin{array}{l}\text { The international activity } \\
\text { provides incentives for } \\
\text { decision-makers to } \\
\text { optimize returns }\end{array}$ & $\begin{array}{l}\text { Small board size } \\
(5-7)\end{array}$ \\
$\begin{array}{l}\text { CEO is also } \\
\begin{array}{l}\text { Board's } \\
\text { Chairman }(\text { by } \\
\text { majority) }\end{array}\end{array}$ & $\begin{array}{l}\text { Company's directors } \\
\text { are also board-members } \\
\text { (by majority) }\left({ }^{*}\right)\end{array}$ & $\begin{array}{l}\text { A starting trend to } \\
\text { adopt more structured } \\
\text { governance systems }\end{array}$ & $\begin{array}{l}\text { A hesitation is } \\
\text { noted to evaluate } \\
\text { CEO \& his/her } \\
\text { performance }\end{array}$ \\
$\begin{array}{l}\text { No external } \\
\text { board members } \\
\text { (by majority) } \\
(* *)\end{array}$ & $\begin{array}{l}\text { Frequent board } \\
\text { meetings }\end{array}$ & $\begin{array}{l}\text { Boards contribute } \\
\text { most to strategic process }\end{array}$ & \\
\hline
\end{tabular}

Source: author, based on authors’ paper. $\left(^{*}\right)$ Stelmar shipping company adopted this. $\left(^{* *}\right)$ The Vafias group, presented in Goulielmos (2020), had external board members.

${ }^{8}$ Notable is that out of 56 quotations only 4 are maritime of which one in Norwegian...

${ }^{9}$ The paper showed indirectly the poverty of research on matters of companies, which are thought to be confidential. From 84 quotations only $15 \%$ were shipping and from them some hardly relevant to paper's topic. 
founded in 1992 by Stelios Hadjiioannou of a Cypriot family of shipowners, and listed in NYSE in 2001. This was a case of confrontation between owner Stelios and 2 members of company's Board of Directors (CEO and CFO). So, first lesson is one to be careful about what members one invites in company's board ${ }^{10}$, and what $\%$ of shares has the founder, being that not below $51 \%$. Shipping business reality has taught us that the personal interest is above company's interest, despite what Fayol ${ }^{11}$ asked for in 1916. Fayol advanced 14 principles of management (Robbins \& Coulter, 2018: p. 70), of which one said: "subordination of individual interests to the general interest"! Stelmar finally sold ${ }^{12}$ to OSG- Overseas Shipholding Group in 2004 against $\$ 843 \mathrm{~m}$.

Lorange \& Fjeldstad (2010) posed one question and gave a positive answer with 3 reasons. The question was: Does the organization of international shipping companies deserve special attention? They recognized that shipping has a more important and effective role to play after the opening-up of the new trades with over-populated areas, like China and India, and other S E Asia countries. Given market's volatility companies had to be organized and managed properly to make high stakes and rapid asset-playing decisions (Graph 2).

A Greek shipowner (Danaos) said that globalization made possible by containerization. In what particular way shipping helps humanity? Table 2 illuminates this.

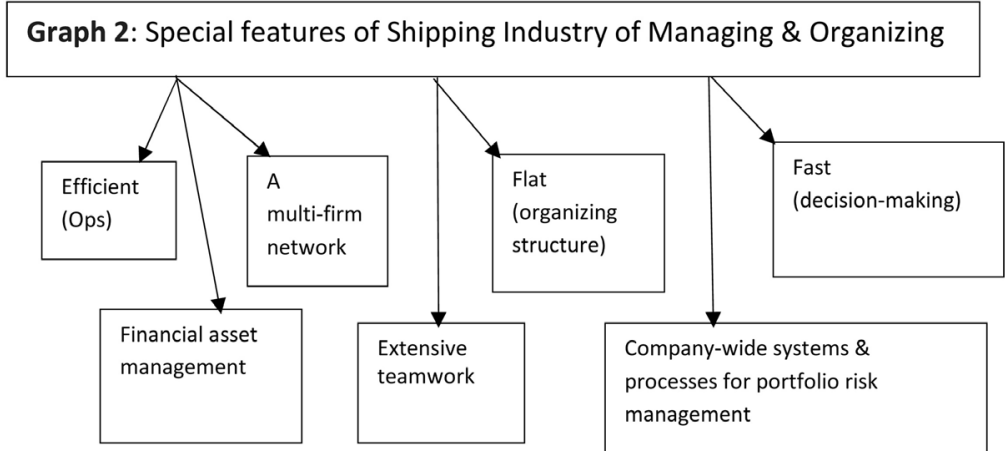

Graph 2. Special features of shipping industry of managing \& organizing. Source: author, from the paper mentioned.

Table 2. Ships and their particular \% role in the transport (shipments) of certain cargoes.

\begin{tabular}{cccccc}
\hline Type of ship & Phosphate rock & $\begin{array}{c}\text { \% of total cargo in } \\
\text { Iron-Ore }\end{array}$ & Coal & Grain & Bauxite-Alumina \\
\hline Capesize & - & $70 \%$ & 45 & 7 & - \\
Panamax & 20 & 22 & 40 & 43 & $45 \%$ \\
Handy & $80 \%$ & 8 & 15 & $50 \%$ & $55 \%$ \\
\hline
\end{tabular}

Source: Data from fearnleys' \& LSE, undated.

${ }^{10}$ Worth noting is that Stelios had a $13 \%$ of company's shares, his brother Polys had $7 \%$ and her sister Clelia had $7 \%$, a total of $27 \%$.

${ }^{11}$ Translated into English in 1949 by Sir Isaak Pitman \& Sons, Lon.

${ }^{12}$ If a buyer agrees to retain certain members of the boards of directors after sale of the company, these agree strongly for this take-over! 
As shown Capes carry the majority of iron-ore required for buildings, public works etc., along with Handy carrying bauxite and alumina, and feeding people with Grain. This last type helps also agriculture (80\%). Capes and Panamax help with coal, as a source of energy, almost equally. This is a pre-China etc. picture as China is not mentioned and India is mentioned for providing iron-ore to Japan and Korea. China dominated the iron-ore transport gradually since 1986 with $190 \mathrm{mt}$, in 2004, out of $590 \mathrm{~m}(\sim 32 \%)$.

Moreover, Lorange \& Fjeldstad (2010) pointed-out further the changes that occurred in shipping industry since 1990 (Graph 3).

Managers have to realize the main characteristics of Shipping Industry (Graph 4).

Summarizing, we believe that managing shipping companies is better to be one-man show, and decision-making to be again one-man show, but this has to come out with a contribution from all relevant departments. Family structures in Greek shipping maintain family hierarchy in decision-making and this is more

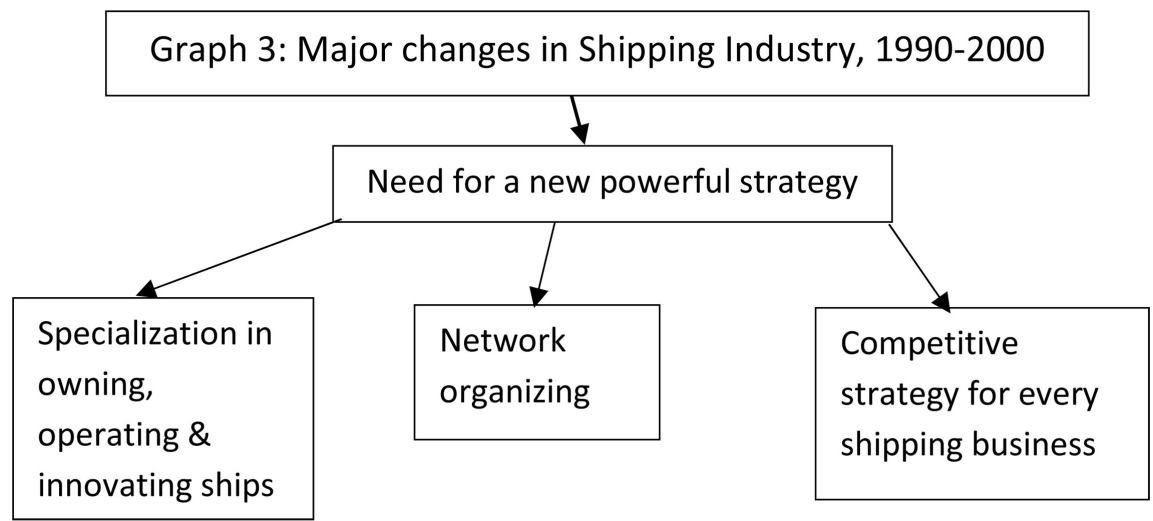

Graph 3. Major changes in Shipping Industry, 1990-2000. Source: author, based on paper mentioned.

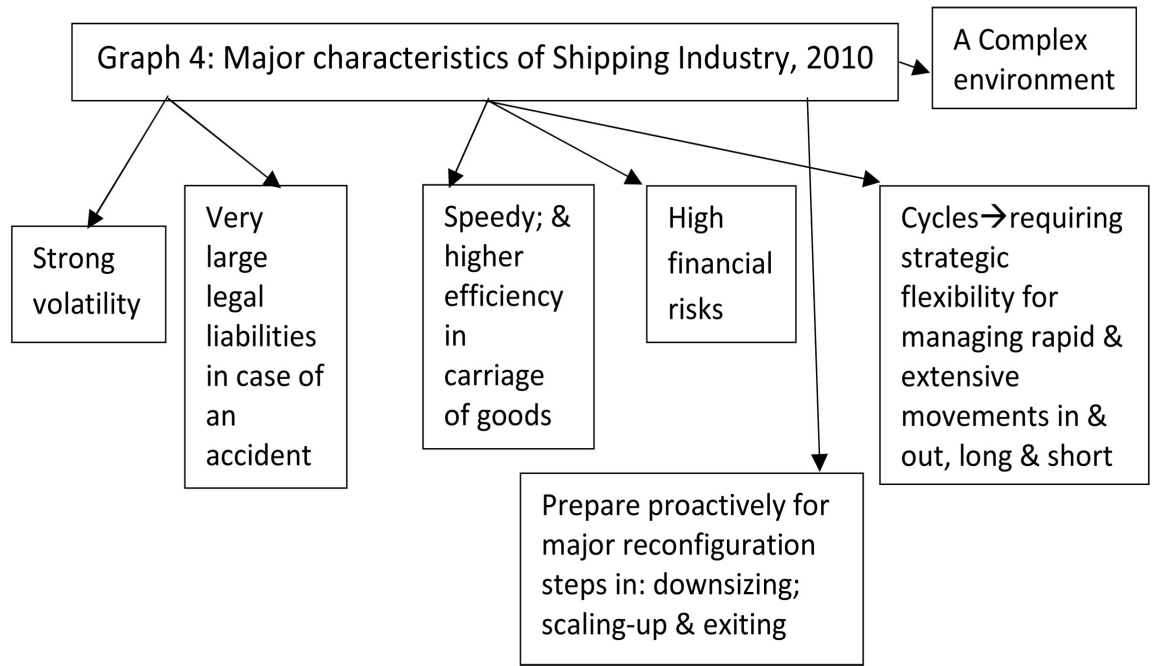

Graph 4. Major characteristics of Shipping Industry, 2010. Source: author, based on paper mentioned. 
effective. When there is a disagreement, father's opinion prevails, but when father dies sons or daughters set-off in their new individual companies. This also has happened with brothers (Polemis; Procopiou; Martinos and others).

Perfect timing, however, is the King and the successful shipping managers have done it. Greeks by using a number of economic principles succeeded to excel and to approach, but not to reach perfect timing. This we believe is the top criterion of managing and organizing a shipping company successfully. By pursuing a perfect timing, this presupposes certain times waiting with utmost patience. Let us take an example in answering the question: when was a perfect timing to order and build tankers between 1980 and 1992 (January)? This is shown in Figure 1.

Figure 1 indicates that the lowest price, over the 1980-1992 period, to build a VLCC is in Jan. 1986. This consists a perfect-timing (with probable delivery in 1988 Jan.). The competitive advantage of such a decision is obvious: one has to pay $\$ 38 \mathrm{~m}$ for a VLCC, against what he/she should pay in 1991 of $\$ 95 \mathrm{~m}$. The later owner will have a higher capital cost of $\$ 57 \mathrm{~m}$ and for a 15 - yearly lifetime of the ship $\$ 10,411$ per day additional cost. However, to build a ship cheaply is one important factor, but to earn maximum earnings is another (Figure 2). Figure 2 indicates that the highest earnings are obtained in March 1991, and in May 1991, and not in 1986 Jan. What one has to do (Table 3)?

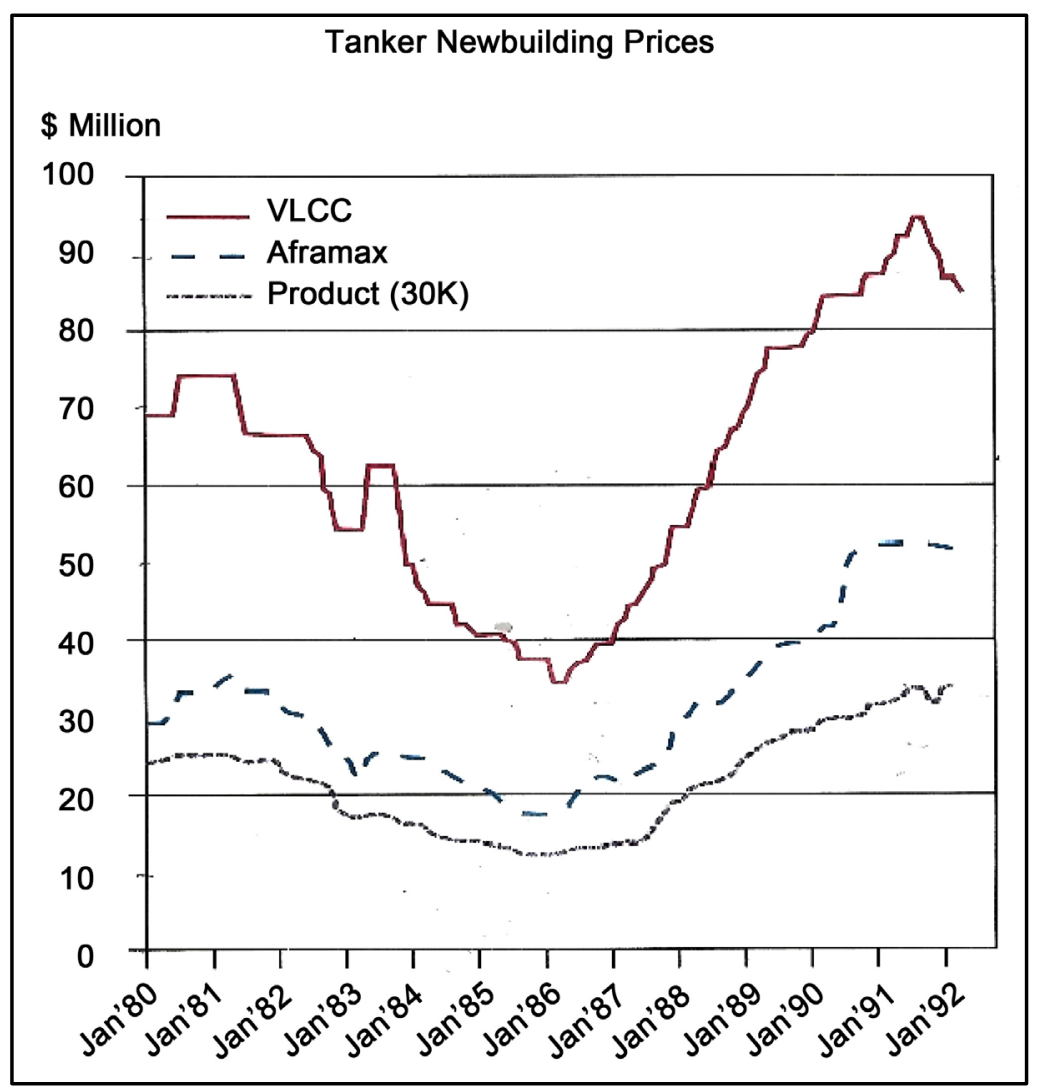

Figure 1. Prices for newly-built tankers, 1980-1992 (Jan.). Source: Clarkson Research Studies Ltd. 


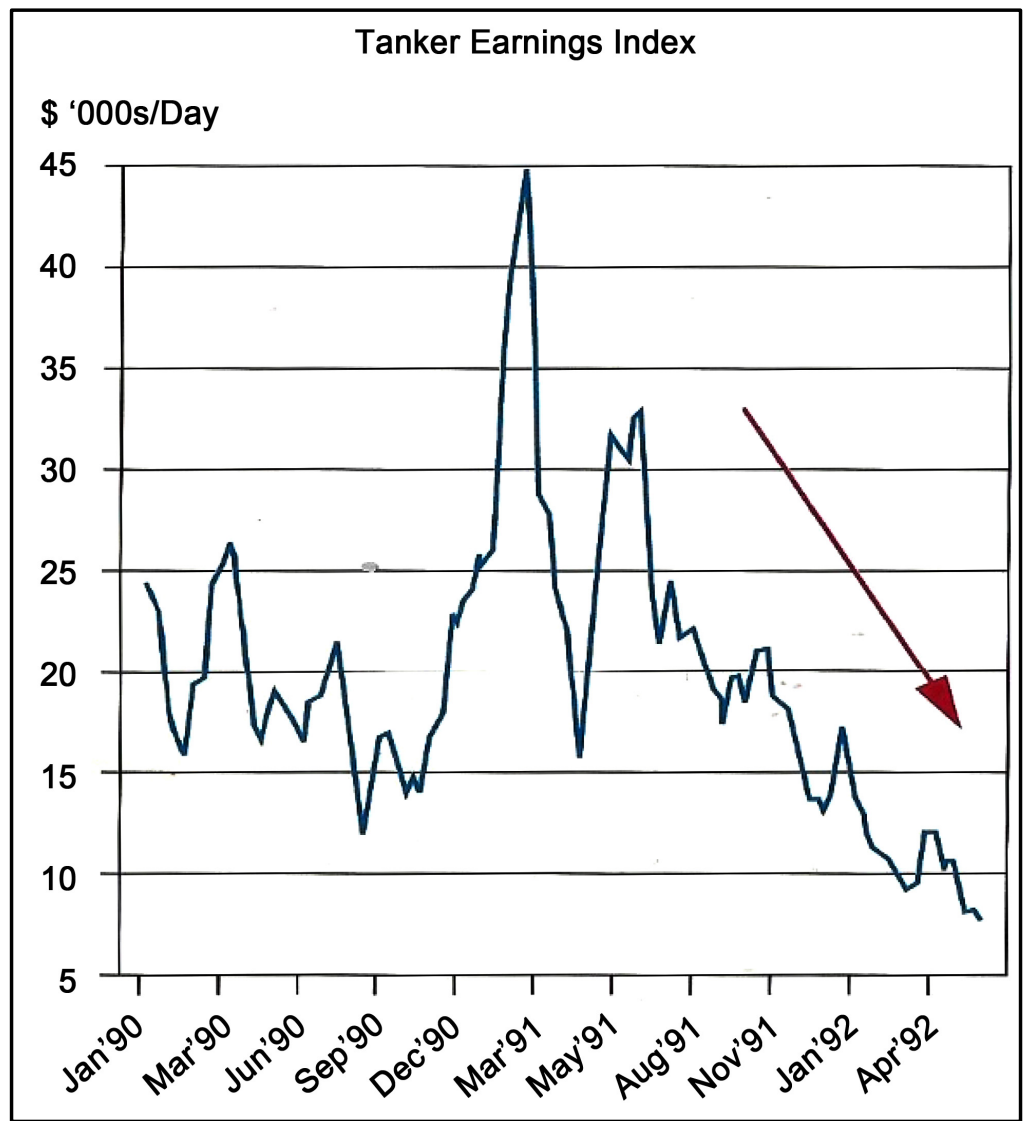

Figure 2. Tanker earnings, 1990-1992 (April). Source: Clarkson research studies ltd.

Table 3. Perfect timing for building and for earnings.

\begin{tabular}{ccccc}
\hline $\begin{array}{c}\text { Perfect } \\
\text { timing to } \\
\text { build }\end{array}$ & $\begin{array}{c}\text { Delivery } \\
\text { (probably) }\end{array}$ & $\begin{array}{c}\text { Per day } \\
\text { earnings }\end{array}$ & $\begin{array}{c}\text { Earnings }{ }^{13} \text { for a hire } \\
\text { of } 38 \text { months, from } \\
\text { 1988 Jan.-to 1991, } \\
\text { March }\end{array}$ & Remarks \\
\hline 1986 Jan. & 1988 Jan. & $\begin{array}{c}\$ 15,000 \\
\text { hypothetical }\end{array}$ & $\$ 16.62 \mathrm{~m}$ & $\begin{array}{c}\text { A low freight rates } \\
\text { period }\end{array}$ \\
$\begin{array}{c}\text { Perfect } \\
\text { timing for } \\
\text { earnings }\end{array}$ & March 1991 & $\$ 45,000$ real & $\begin{array}{c}\text { Earnings for hire in } \\
1991-1994 \text { for: } 38\end{array}$ & $\begin{array}{c}\text { Price difference } \\
\text { months }=\$ 49.93 \mathrm{~m}(80-38)\end{array}$ \\
$\begin{array}{c}\text { Bad timing to } \\
\text { build: } 1989\end{array}$ & 1991 March & Price $\$ 80$ & $\$ 49.9 \mathrm{~m}$ & $\begin{array}{c}\text { Earning difference } \\
\$ 33.31\end{array}$ \\
& & & & $\$ 49.93-\$ 16.62=$ \\
& & & & $\$ 33.31 \mathrm{~m})$ \\
\hline
\end{tabular}

Source: author.

As shown, the perfect-timing for building is in 1986, at $\$ 38 \mathrm{~m}$ and this provides a benefit of $\$ 42 \mathrm{~m}$, against $\$ 80 \mathrm{~m}$, which is the price prevailing in 1989 (the year of perfect timing for earnings). Thus, a theoretical loss comes from the

${ }^{13}$ Earnings are always calculated for 350 days per annum, while cost over 365 days. 
lower earnings of $\$ 30,000$ per day and for 350 days or $\$ 33.31 \mathrm{~m}$ for a hypothetical hire of 38 months (1988-1991). There is a final surplus (42 $\mathrm{m}$ from building prices) and a $33.31 \mathrm{~m}$ loss from earnings, which gives a final $\$ 8.69 \mathrm{~m}$ benefit, between the two perfect-timing decisions to build and to charter. Thus, this whole example is in favor of building cheap and the suggestion is to order at a rock-bottom newbuilding price no matter what the freight rate is.

Part I: The case-study of the 107 ships built for Liberty in 1941-1945.

The end of $2^{\text {nd }}$ World War found USA with 2751 laid-up commercial ships, which built in 17 USA shipyards (from 27/09/1941 to 30/10/1945), of about $27.5 \mathrm{~m} \mathrm{dwt}$, for the war. They were built for the $1^{\text {st }}$ time using the "electro-welding" method in fixing (the iron) plates together, instead of using iron rivets, as hitherto, something which made ships heavier ${ }^{14}$. USA's aim was to build these ships fast, so that to replace the vessels foundered by German submarines... They were named "Liberty" ships (Scan 1) indicating their purpose to contribute towards world's liberty. Their cost was about $\$ 2 \mathrm{~m}$ each.

USA, after the war, wanted to dispose (lend-lease) abroad above Liberties at favorable terms with a credit facility ${ }^{15}$. Greek shipping had losses during $2^{\text {nd }}$ World War amounting to $72 \%-75 \%$ of its 1938 fleet (GRT). Onassis calculated that Greeks lost ships valued $\$ 153 \mathrm{~m}$ during the war (an amount received-back partly from insurance compensations and partly from companies' profits). Greek shipowners in order to invest these funds, which were held by Greek State, in a more secure way, wanted to buy 100 Liberty ships.

Greek State intervened to USA so that Greeks to obtain 98 Liberty ships ( $\$ 550,000$ each; $25 \%$ cash; $75 \%$ in 17 annual installments; at 3.5\% interest rate and Greek state's guarantee). Latter this modified and shipowners paid 50\% cash

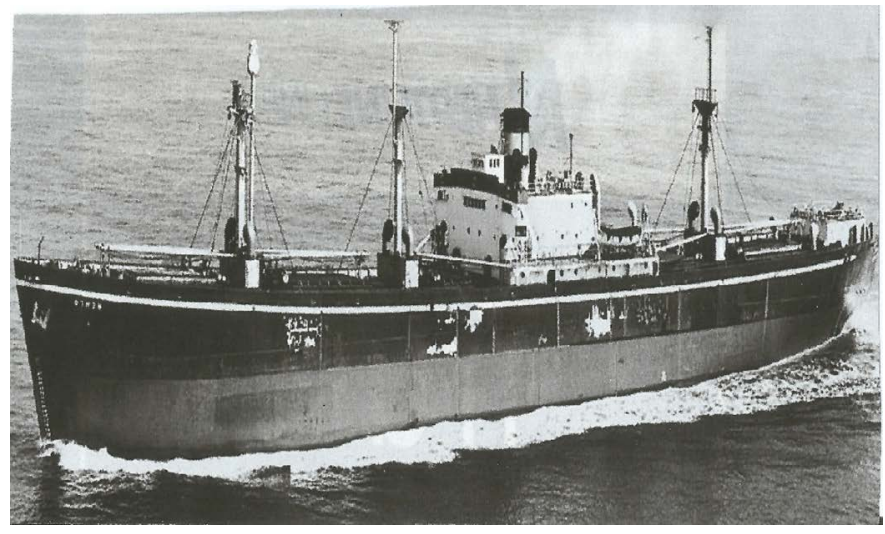

Scan 1. One liberty out of 98 sold to Greeks by USA, 1947. Source: Argo shipping periodical, 1986; modified.

\footnotetext{
${ }^{14}$ Indirectly we see here the remarkable technological advance by going from iron to steel! Ships became lighter, and thus larger, plus other benefits. Japanese have invented also an even lighter steel. Some have wondered if these ships built with "improved" steel plates, produced less resistance in bad weather, and thus more marine accidents?

${ }^{15}$ The history is repeated, however, as something similar happened at the end of Great War in 1918, where more than 4000 sailing ships were laid-up in Danube, and other rivers, most bought by Greeks.
} 
and a $10 \%$ of ships' value only guaranteed ${ }^{16}$. A $1^{\text {st }}$ mortgage on their $50 \%$ value was written in favor of Greek State. These ships had, however, to flow Greek flag and employ Greek crews.

The ships for Liberty underwent repairs of about $\$ 100,000$, or over, each; in addition, Greeks obtained and 7 T2 tankers at a price round $\$ 2 \mathrm{~m}$ each. The 107 Liberty ships of about 730,000 GRT were the only solution, at that time, for Greek shipowners as Greek shipyards did not exist and funds in US \$ were also not available...In 1948, Greeks owned ships amounted to $2.52 \mathrm{~m} \mathrm{GRT;} \mathrm{and} \mathrm{over}$ $364 \mathrm{~m}$ dwt by 2020 !

The buyers had to have US\$-Greek shipowners had only English pounds ${ }^{17}$ also bound (locked by Greek State) in UK banks- and the transfer into \$ was complicated. Global shipping demand was in hands of USA, as it has not been involved in the war from the beginning. The Liberties covered up to $58 \%$ of Greek flagged shipping in 1948-1949 and remained 40 years in the fleet $(-1986) . .$. Thus they produced a great advantage and benefit to Greek flagged shipping. In addition, Greece received, in kind, a gesture of gratitude for fighting for liberty in allies' and USA's side and paying a toll.

Moreover, the Greek state organized the entire project together with "NY Greek shipowners". The 2 first criteria set for one to buy the Liberties were fair, we believe: 1) Greek owners should have lost ships during the War, and perhaps to receive ships in analogy of losses suffered, and 2) to have flown Greek flag. And 3) to be members of the "NY Greek shipowners' union"-something we consider to be unfair. Onassis had none of the above criteria...A number of 47 Greek shipowning-families, or 66 shipowners-traditionals, obtained 98 Liberty $^{18}$.

A list of Greek shipowners, who bought the 98 Liberties can be found in Goulielmos (2020).

\section{Part II: Onassis ${ }^{19}$ Business Life ${ }^{20}$ : A Case-Study ii}

We were impressed by Onassis, $\mathrm{O}$ thereafter, written will establishing the

\footnotetext{
${ }^{16}$ State's guarantee was for $\$ 40 \mathrm{~m}$-ended in 1954 and in 1955; shipowners' counter-guarantee was \$5.5m, which ended in 1954 and 1955 too (Laws 747 and 150/1946).

${ }^{17}$ The ships lost due to war-cause were insured in UK insurance market for war-risks and thus Greek shipowners had $£$ funds to buy Liberties.

${ }^{18}$ Sixty-six (66) ships obtained by 18 traditional families; these families that have obtained more than 1 Liberty were: Fafalios 2, Andreadis $\left(^{*}\right)$ 2, Vergotis 3, Goulandris $\left.{ }^{* *}\right) 3$, Gratsos $\left.{ }^{(* *}\right)$ 4, Elliniki 4, Epiphaniadis 3, Kassos SA 3, Kulukuntis 7, Livanos 11, Lemos( $\left.{ }^{* * *}\right)$ 5, Los 2, Michalinos 2, Nicolaou 2, Nomikos $\left(5^{\star}\right)$ 2, Kumantaros 4 (1 with $\operatorname{Niarchos}\left(6^{*}\right)$, Pateras 5 \& Stathatos 2. $\left(^{*}\right)$ He was born in Chios (Vrontados) in 1905. A University Professor. He passed away in 1989. (**) V.J. was an M.P. born in Andros in 1886 and Captain. In 1925 established -with his brothers-the company "Goulandris Bros Ltd". (***) Born in Kassos in 1898. He passed away in 1998. (***) Lemos, C M born in Oinousses in 1911 and passed away in 1995. One of the 5 major global shipowners. In 1937, together with his cousins Costas and Markos Lyras, established -in London- the shipping office: "Lyras \& Lemos". After $2^{\text {nd }}$ World War went to NY. $\left(5^{*}\right)$ Lukas Nomikos born in Oia next to Santorini in 1886 and was a seaman. He passed away in 1937. (6*) Born in Athens in 1909 and passed away in 1996. He was among the top shipowners by 1957 and a Golden Greek.

${ }^{19}$ Onassis born in Smyrni in 1900. His birth date is... movable as the situation required (!). To avoid being transferred to Turkish concentration camps, he was under 17; to get a work permit in Argentina was 18.

${ }^{20}$ For the first part see Goulielmos, A.M. (2020).
} 
"Alexander S. Onassis Public Benefit Foundation". O’s company, "Springfield" owned, in 2018,6.08m dwt and 30 ships. The company more than doubled its fleet dwt since 2010. Onassis is shown in 1932 with one of his 6 second hand ships bought from a Canadian company (Scan 2).

\subsection{The Investment Policy of Onassis}

As shown, Onassis changed the investment strategy of traditional Greek shipowners. Greek shipowners used to buy 1 ship at a time, using past profits. They used also to buy first, and then sell, till this day. This policy apparently could not help a shipowner to grow fast. Moreover, few of them dreamed to build a newbuilding, considered to be an adventure.

We have to admit, however, from the start, that Onassis was lucky-or had he a lucky star? This is so because he lived during a period, where the abundant cheap oil he transported, since 1938, and especially after 1945, was the King in sea transport. This peaked in1967, where Suez Canal closed and created 7 (prosperous) years (till 1974) (Stopford, 2009: p. 123)!

Onassis died in March 1975, 4 years before the disastrous crisis in tankers started (1979). Moreover, O exploited the possibility to obtain finance, for expansion, away from own profits, which anyway were limited to accomplish a champion's vision, as mentioned... In fact, Norwegians, at that time, used to acquire tankers on "time charter-backed" credit ${ }^{21}$ during interwar period. O improved the above method by ordering a series of same vessels ("sisters") at one shipyard. He obtained lower prices due to "learning by doing 22 " (economies from building ships in series and in mass). $\mathrm{O}$ used for this a single charter to back-up his loan (Harlaftis, 1993) (Graph 5).

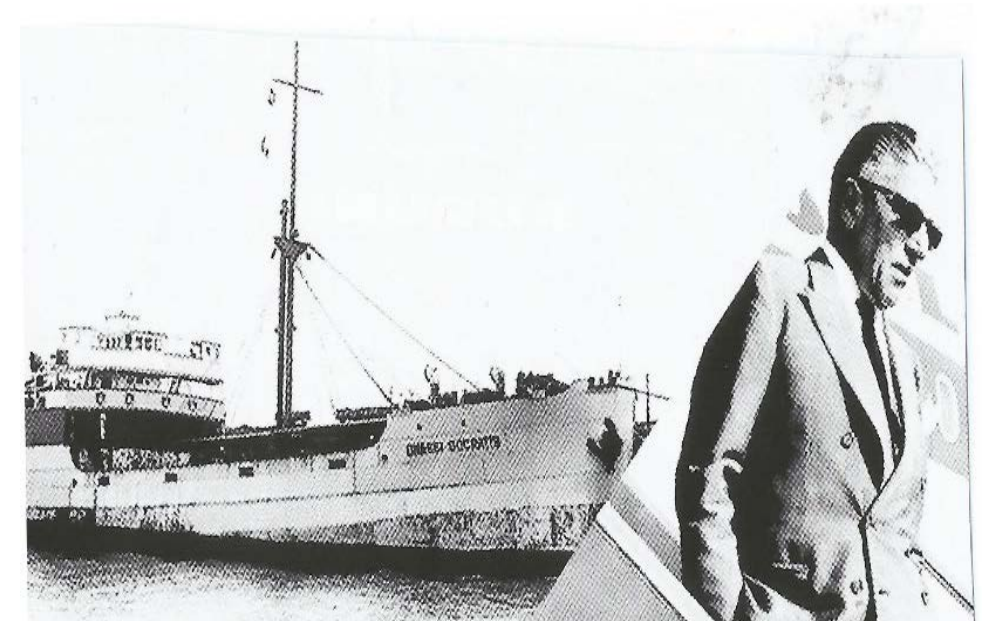

Scan 2. Onassis with his vessel M/V “Onassis Socratis”. Source: Panama's register.

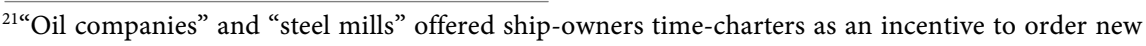
ships, where the owners could raise a loan to buy the ship against the security of a time-charter (Stopford, 2009: p. 272). This started in 1920s and peaked during 1927 in particular.

${ }^{22} \mathrm{Applied}$ for the first time in the construction of Liberty ships by Kaiser (USA).
} 


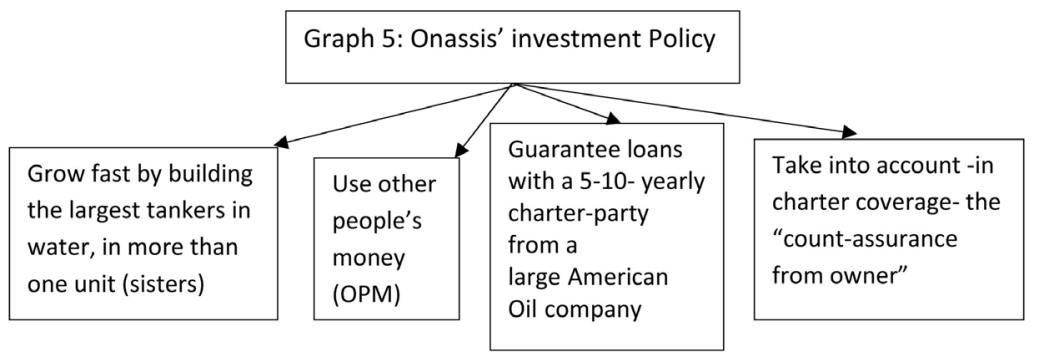

Graph 5. Onassis' investment policy. Source: author.

Perhaps the above idea, (series and mass production), followed also by Ford in the construction of cars. Japanese applied this philosophy after the war introducing also robots, steel, computerized designs and steel cutting, heavier cranes, longer launching quays, so that to minimize time and cost of building a series of standard vessels, with no influence from weather...

Another event that benefitted Onassis or induced him to enter the tanker market was Norway's foreign exchange policy (Harlaftis, 1993). Norway, in 1948, was in foreign exchange shortage, and so it imposed a ban on the imports of ships (1948-1951). Norwegians who were heavily involved in tankers in the interwar period failed to benefit from the increasing demand created by Korean War (1950-1951)!

O opened the American financial markets to Greek shipowners (Harlaftis, 1993). O in order to bend the opposition of the USA financial institutions ${ }^{23}$ to accept the "standard charter clauses"-persuaded "Socony Oil" to take into account in charter coverage the "count-assurance from owner". O obtained also from Grand "Metropolitan Life Insurance" (NY) Co a loan of $\$ 40 \mathrm{~m} .$.

\subsection{Onassis "Reconstructs" the German Shipbuilding Industry (1951)!}

O saw in Germany's destruction from $2^{\text {nd }}$ World War, the great opportunity to build there his future vessels! The "Potsdam 1945 agreement", however, prevented him for building large tankers till 1951. The "Hamburg shipyard" told O that an order of 16 tankers is needed for this yard to be completely reconstructed. $\mathrm{O}$ immediately organized a $\$ 100 \mathrm{~m}$ loan and placed orders for $16+2$ tankers in 3 German shipbuilders: at Kiel, Bremen and Hamburg! Kiel yard delivered, in 1953, 2 vessels, one of which named "Tina Onassis" (45,230 dwt) ${ }^{24}$, called "supertanker" accumulated large profits during $2^{\text {nd }}$ World War by using flags of neutral countries, like Panama and Sweden.

\subsection{The "Ill-Fated" Saudi Arabia Deal (1954)}

This was O's greatest mistake, though it was a clever idea; also, this mistake was

\footnotetext{
${ }^{23}$ Between UK and USA there were two bases of financing: on mortgage and on charter parties respectively.

24“"Howaldtswerke" shipyard (Hamburg).

25“'Sumitomo" later delivered a tanker of 300,000; really a newer super-tanker (1973).
} 
admitted by $\mathrm{O}^{26}$. In Jan. 1954, O, all suddenly, signed a deal with Saudi Arabia, which shocked the oil and shipping world, with its global repercussions (Graph 6).

The whole package of O was a clever "win-win" case. Feroudi (2011) argued that $\mathrm{O}$ was a clever businessman, and in any business deal, he knew how to get what he wanted (p. 203). O, however, was not able to beat the 4 powerful oil majors $^{27}$...This deal called -by "oil alliance" a "red line" one...These four through Aramco-dominated, long before, over Country's oil transport, and also on the exploration and production of oil for almost 70 years. In 1954, O took delivery of his 47,000-dwt tanker built in Hamburg, named with a special meaning: "Al-Malik Saud Al-Awal"...The 4 oil majors boycotted O's tankers, and forced the whole deal into a long term-with no visible end-arbitration...

In July 1956, Egypt "flirted" with Russia. This led USA to withdraw from Nile's dam project; Egypt expected to try to nationalize and close Suez Canal in retaliation. In such a case, ships had to travel via the Good Hope cape, an almost double distance. Hires from $\$ 4$ a barrel went up to over $\$ 60$; the "tanker Worldscale index" went up at 460 (from W220). O faced rough times, when 1/2 of his tankers were laid-up; he then tried to have a charter with BP. Finally, "Socony Oil" chartered M/T "Al-Malik"...due to his lucky "star"? Britain, France and Israel warred with Egypt in October 1956 and the Suez Canal closed (1956 Oct.), but reopened in April 1957; Onassis was the only major shipowner with most of his fleet in ballast, due to the prior boycott.

The net profit for $\mathrm{O}$ was $\$ 75 \mathrm{~m}-\$ 80 \mathrm{~m}$ for less than 7 months for the short-time of Suez Canal's closure... and $\$ 2 \mathrm{~m}$ for one crossing from Persian Gulf to Europe. This, however, worked-out as a trap, because Onassis stuck ("locked-in" in "Chaos Theory terminology") in the spot market. The freight rate soon fell below W100. O overlooked the option he had for time charters at a

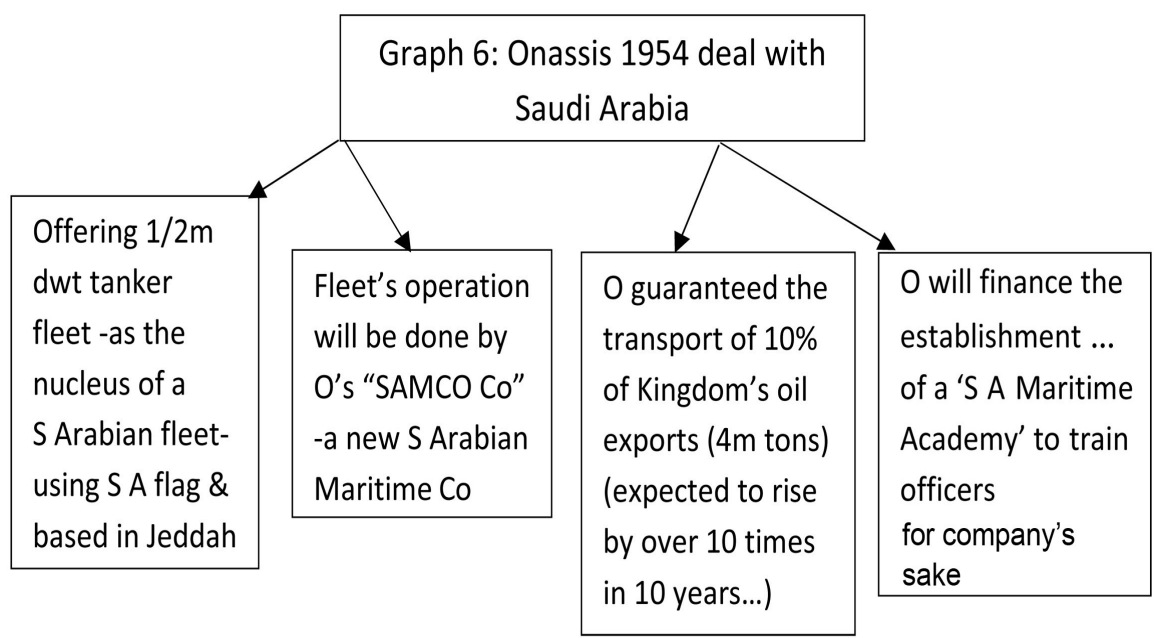

Graph 6. Onassis 1954 deal with Saudi Arabia. Source: author.

${ }^{26}$ Forestie, F. (2009).

${ }^{27}$ Standard oil; Mobil; Exxon and Texaco. 
lower, but more stable, hire. Onassis failed also to foresee the quick re-opening of the Suez Canal within six months unlike Gratsos C, who foresaw it...

\subsection{Onassis' Shipbuilding Program, 1948-1975}

$\mathrm{O}$ was a shipowner of a continuous shipbuilding! He reached 41 units of newly-built tankers of a higher quality. Finally, 97 orders-almost 3 ships p.a.-were recorded for him over 28 yards... The $80 \%$ of them were tankers, dominated by VLCCs-very large crude carriers. From the 18 bulkers 11 of them were of small size round 27,000 dwt.

As shown, O ordered about $7 \mathrm{~m}$ tons since 1948.

As shown, 1965 and thereafter were the years at which the shipbuilding program of O rose by leaps and bounds, till 1973 (Figure 3).

To the picture helped VLCCs due to their size. The year 1958 was a crisis one for shipping; $\mathrm{O}$ cancelled a number of shipbuilding contracts, including the 3 tankers that planned to be built in "Bethlehem Steel" (USA), under the "scrap and build" program of US Maritime Commission. Crew wages cut by $20 \%$. O continued to use foreign flags, because, as he said, they allow: "free competition; ability in taking initiatives, and imposing no restrictions"...

The $2^{\text {nd }}$ Suez crisis, during the 6-day war in June 1967, triggered a rush by leading owners to invest in larger tankers-able to travel round the Cape of Good Hope. Israel did a pre-emptive strike against Arab targets. $\mathrm{O}$, few days after this, offered BP all his off-charter fleet at $200 \%$ of existing freight rates. BP accepted...; the rates in few days, however, doubled. This was a hasty action of $O$, depriving him from a much larger profit. This mistake is committed and by other Greek shipowners.

\subsection{Onassis' Fleet Growth 1958-1981}

The growth of "O's fleet" from 1958 to 1981 in GRT is shown (Figure 4).

As shown, O climbed-up in shipowners with over $2.5 \mathrm{~m}$ tons GRT in 1975.

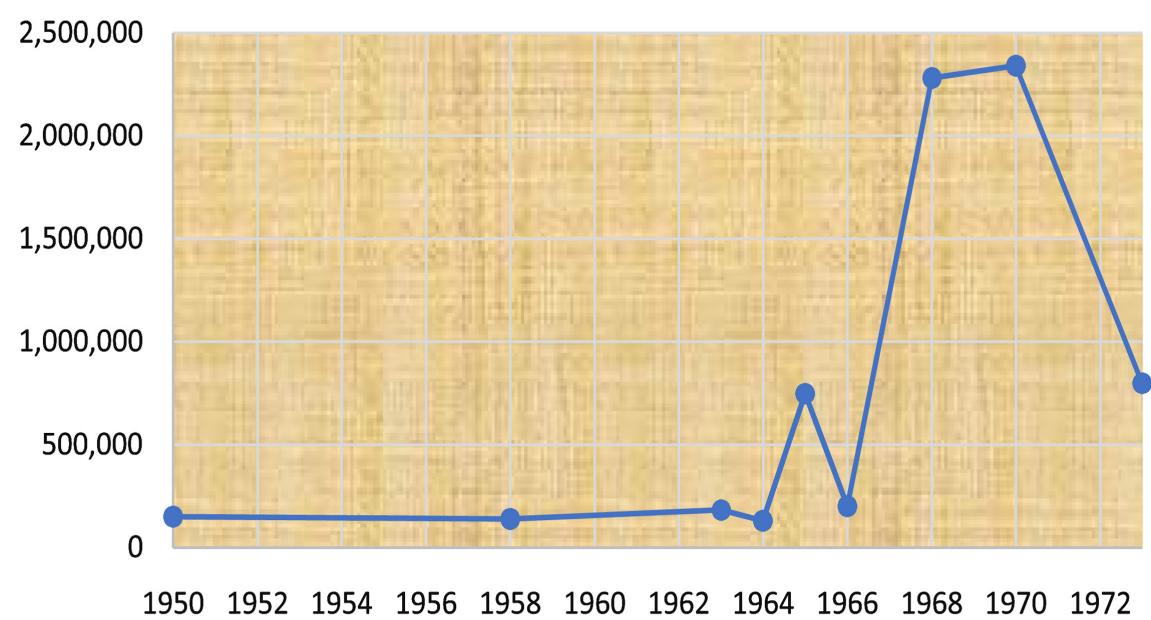

Figure 3. Onassis's shipbuilding program 1950-1973 (in dwt). Source: author. 


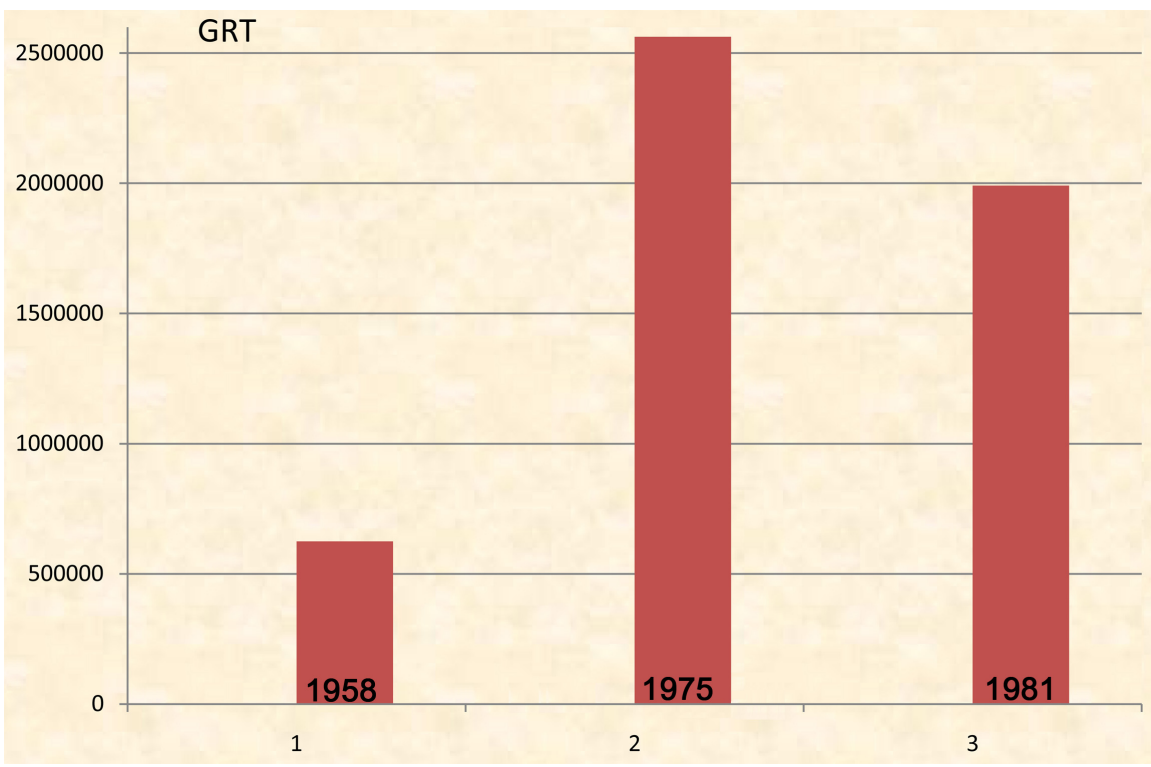

Figure 4. Onassis' fleet growth in 1958, 1975 and 1981 in GRT. Source: Data from Kapsi N. (2005). Source: Data from Kapsi N. (2005).

\subsection{Onassis as Investor (1960s)}

As investor ${ }^{28}$, O, bought thousands of BP shares in 1960s, as a good gesture to $\mathrm{BP}$, which played a key role in restoring his fortune. He bought the "Banque de Depots" in Geneve-a bad investment which later sold to Latsis J. In 1970, O bought 100 tons of gold valued $\$ 100 \mathrm{~m}$. Three years later, when gold sold, valued $\$ 357 \mathrm{~m}$. This was also a hasty sale as prices went-up further. In the real estate, he built the 'Olympic Tower', a 50:50 joint venture, and a 51-storey skyscraper in Manhattan's Park Av. of 225 apartments and 420,000 square feet of office and retail space. In end 1968, the "Northern Ireland project" was an effort of O to buy-out the "Harland \& Wolff" shipyards (Scotland). O had already 26\% of company's shares. In 1968, he placed there an order for $2 \times 265,000 \mathrm{dwt}$ tankers at $\$ 12.6 \mathrm{~m}$ each. This deal failed (1971).

$\mathrm{O}$ used to conduct talks personally with either union leaders, or even terrorists, as happened in 1968 and in 1970. In 1963, $4 \times 46,000 \mathrm{dwt}$ tankers delivered to an O's company in USA ("Victory"), serving US domestic trades; these ships were small. In 1966, 2 of O's tankers-including the Al-Malik...had a fire in engine room and declared constructive total losses-i.e., beyond any economical repair. Bad luck.

Table 4 summarizes the wealth ${ }^{29}$ of O by 1973-1974.

\subsection{Onassis and the End-1973 Shipping Crisis}

In 1973 (summer), a success story for VLCCs and ULCCs (Ultra large crude carriers) has been written, when the spot market was improving. O owned then 100 ships and had a profit of $\$ 144 \mathrm{~m}$ p.a. The global oil consumption increased by at

\footnotetext{
${ }^{28}$ We will not deal with the "whale-fishing" businesses, confronted with Peru's Government (1949).
}

${ }^{29}$ Published in “Economic Postman” (in Greek: “Oikonomikos Tachidromos”), $3^{\text {rd }}$ July 1975. 
Table 4. Onassis value of investments, 1973-1974.

\begin{tabular}{ccccc}
\hline $\begin{array}{c}\text { Country of Onassis } \\
\text { Company }\end{array}$ & Area of investment & Amount in US\$m & Area of investment & Amount in \$m \\
\hline $\begin{array}{c}\text { Europe, L. } \\
\text { America \& USA }\end{array}$ & Buildings \& Tourism & 126.0 & General enterprises & 116.0 \\
& Finance \& Banking & 6.5 & Transport & 196.5 \\
& Industry & $518.037 \%$ & Shares & $317.023 \%$ \\
& Shipping & 78.5 & Brokerage & 22.0 \\
& Mortgages & 17.0 & Total & $\sim \$ 1.4 \mathrm{~b}$ \\
\hline
\end{tabular}

Source: “The Financial Postman" journal. Kapsi (2005). Note: some data is from Harlaftis (1993: p. 192). The above list of O's wealth is an underestimation: it excludes wealth in Asia; also, deposits in 217 banks; the value of O's bank in Switzerland; the value of shares in Harland \& Wolf; the value of Skorpios' island; the value of NY skyscraper and the value of O's fleet of 56 ships of $2.5 \mathrm{~m}$ dwt, plus $1 \mathrm{~m}$ ounces of gold, valued $\$ 170 \mathrm{~m}$ (1974). Given that O left to his heirs $\$ 500 \mathrm{~m}$, this means that part of his wealth lost in unfortunate projects like "Olympic Airways", we believe.

least $8 \%$ per year and almost $9 \%$ in USA (covering the $40 \%$ of total transport). O ordered 4 tankers of $>200,000$ dwt each in Japan and 2 ULCCs in France (Table $5)$.

In October 1973, Arabs reduced the production of oil to prevent the West from helping Israel in the $4^{\text {th }}$ "Arab-Israel" war. O's $1 / 3$ of his fleet was laid-up. He cancelled 2 VLCCs ordered in France by paying a $\$ 12.5 \mathrm{~m}$ penalty. The situation led people to changes-like their efforts to save energy, to discover new sources of oil and adopt new non-oil technologies, etc. This was the worst tanker crisis that $\mathrm{O}$ faced. Moreover, OPEC raised the price of oil per barrel from \$2.9 to $\$ 13$ (4.5 times).

By 1975 , the overall demand for tankers fell $20 \%$. O was partial lucky for most of his VLCCs were in rather long-time charters with major oil companies, but $1 / 2$ of them were about to expire. All other O's vessels were idle. The few new-buildings had an uncertain future, as there were no charters available. "Sumitomo" delivered the first quality supertanker of 300,000 dwt-as O has asked for -the "Olympic Loyalty" priced $\$ 115 \mathrm{~m}$. This was the highest ever investment in ships, and the $3^{\text {rd }}$ double-hull delivered worldwide. Onassis star fell on earth, however, (Figure 5) when the laid-up tonnage of tankers in 1975 was $24 \mathrm{~m}$ GRT?

During O's life, 2 international conventions were adopted (1974): the MARPOL, with a purpose to limit routine pollution. The new SOLAS (1974), purposed to speed-up measures for passenger ships, but it included special new requirements for tankers, like the IGS (inert gas system) to avoid accidental explosions.

\subsection{Onassis' "Animal Spirits"}

Keynes wrote in 1936-in another context (slightly rephrased): "It is safe to say that the enterprise depends on hope... But the individual initiatives will only be adequate, when reasonable calculations (are) supplemented and supported 
Table 5. Onassis' shipbuilding program, 1948-1975

\begin{tabular}{|c|c|c|c|}
\hline $\begin{array}{l}\text { Vessel's } \\
\text { name }\end{array}$ & $\begin{array}{l}\text { Number/Dwt/tanker/ } \\
\text { delivery or order date }\end{array}$ & Shipyard & Remarks \\
\hline \multirow[t]{18}{*}{$\begin{array}{l}\text { Olympic } \\
\text { Games }\end{array}$} & $1-/ 1950$ & Bethlehem, Baltimore & $\begin{array}{l}\text { The } 1^{\text {st }} \text { built tanker } \\
\text { (out of } 6 \text { ) in USA }\end{array}$ \\
\hline & 2 of $19,000 t / 1950$ & $\begin{array}{c}\text { Bethlehem, Baltimore, } \\
\text { USA }\end{array}$ & \\
\hline & 4 of $28,000 \mathrm{dwt} / 1950$ & $\begin{array}{c}\text { Bethlehem, Baltimore, } \\
\text { USA }\end{array}$ & $\begin{array}{l}\text { To catch-up in size } \\
\text { with the } 4 \text { tankers } \\
\text { built for Texaco. } \\
\text { Amortizable in } 5 \\
\text { years! }\end{array}$ \\
\hline & $\begin{array}{c}2 \text { of } 46,000 \mathrm{dwt} / \text { ordered } \\
1958\end{array}$ & $\begin{array}{c}\text { Bethlehem, Baltimore, } \\
\text { USA }\end{array}$ & \\
\hline & $\begin{array}{c}1 \text { of } 46,000 \mathrm{dwt} / \text { ordered } \\
1958\end{array}$ & Chester & \\
\hline & $\begin{array}{c}4 \text { of } 46,000-47,000 \\
d w t / 1963\end{array}$ & Quincy yard, USA & \\
\hline & 3 tankers & France & \\
\hline & 2 refrigerated ships & Belgium & \\
\hline & $\begin{array}{c}2 \text { of } 65,000 \mathrm{dwt} / \text { late } \\
1957 / 1963-64\end{array}$ & Howaldtswerke & \\
\hline & 3 of $65,000 / d w t$ & Mitsubishi, Japan & $\begin{array}{l}\text { O turned to the } \\
\text { revived Japanese } \\
\text { shipbuilding, offering } \\
\text { generous credit \& } \\
\text { lower cost! }\end{array}$ \\
\hline & 3 of $82,000 \mathrm{dwt}$ & $\begin{array}{c}\text { Ishikawajima Harima, } \\
\text { Japan }\end{array}$ & \\
\hline & 2 of $100,000 t / 1965$ & France & \\
\hline & 4 of $27,000 \mathrm{dwt}$ bulk/ 1965 & Nippon & $\begin{array}{c}\text { Bulkers followed } \\
\text { tankers in the same } \\
\text { course in achieving } \\
\text { economies of scale, } \\
\text { but to a much lesser } \\
\text { range }\end{array}$ \\
\hline & $1 \mathrm{VLCC} / 1966$ & Japan & \\
\hline & 7 of $>200,000$ end 1968 & Japan & \\
\hline & 4 of 220,000 end 1968 & France & \\
\hline & $\begin{array}{c}9 \mathrm{VLCC}^{30} \\
1970 \mathrm{~s} / 260-273,000 \mathrm{dwt}\end{array}$ & Japan, France, UK & $1^{\text {st }}$ VLCC tanker \\
\hline & 2 VLCC of $400,000 \mathrm{dwt}$ & France & Numbers $83 \& 84$ \\
\hline Total & $\sim 7 \mathrm{~m}$ & & $\begin{array}{l}\text { Excluding } \\
\text { refrigerated ships }\end{array}$ \\
\hline
\end{tabular}

Source: various, and especially data from Lowry (2003).

30"Olympic Armour". 


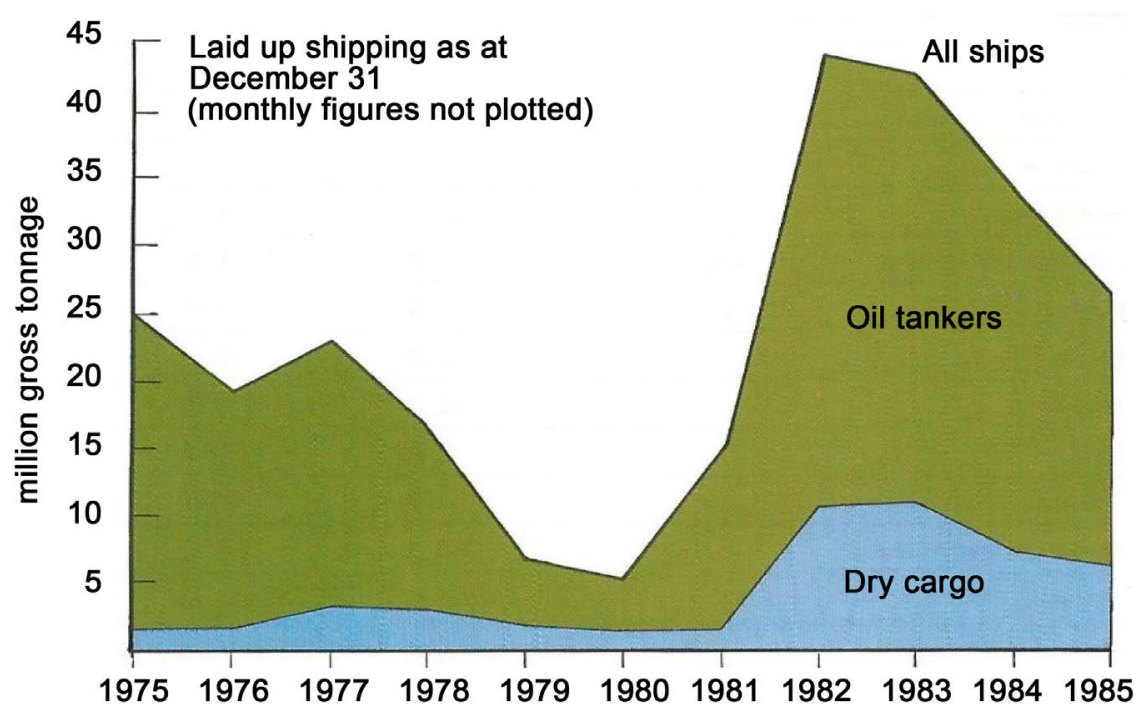

Figure 5. Laid-up tonnage in m GRT between 1975 and 1985. Source: Lloyd; modified.

by animal spirits ${ }^{31}$, so that the thought of ultimate loss, which often overtakes pioneers-as the experience undoubtedly tells us and them-is put aside, as a healthy man puts aside the expectation of death (Keynes, 1936: $\mathrm{p}$. 162). $\mathrm{O}$ already succeeded when he applied his animal spirits and made his first $\$ 100,000$ and more so when he made his $1^{\text {st }} 1 \mathrm{~m} \$$, knowing empirically how one can get a profit from business.

One may wonder why Onassis was dedicated to oil transport, almost exclusively? The answer can be given by the help of Table 6; of course, we took a different period, that of 1997 to 2007, because for this period we have data.

As shown, those shipowners dealing with tankers earned $\$ 143 \mathrm{~b}$ more than those having only dry cargo ships, over a period of 11 years.

\subsection{0’s Win-Win Strategy}

O proved to be a capable negotiator by taking from the other most of what he wanted, offering more or less what the other wanted (a "win-win" strategy). Taking e.g., the case of the German yards: they wanted to reconstruct their industry by building 16 vessels. $\mathrm{O}$ wanted to build cheap ships there, and he ordered $16+2$, and mobilized $\$ 100 \mathrm{~m}$ finance. Who won more does not matter...

Taking also the $\mathrm{S}$ Arabia deal: Arabs wanted to transport their oil in a cheaper and independent way; to create their tanker business-knowhow and their own crews something, which they did many years later. O sought after Arabian cargoes, by creating a $1 / 2 \mathrm{~m}$ dwt fleet -which was easy for him; and he was prepared to pay-out for an "Arab Maritime Academy" from profits...

O did not stop in front of problems, advised by his good friend Costas Gratsos, who knew shipping well. O was self-taught, and an ever-learning person

${ }^{31}$ This explains investors, who put aside the mathematical models on the basis of "animal spirits". A term used by Keynes (1883-1946) to convey the idea that major investments are undertaken, not on the basis of a careful calculation of expected profit, but on the strength of hunches for an opportunity to be grasped out there by whoever had the courage to try... 
Table 6. The profitability between Tankers and Dry Cargoes, 1997-2007.

\begin{tabular}{ccc}
\hline Date, end- & Tanker sector profits \$ billion & Profits dry cargo sector \$ billion \\
\hline 1997 & 23 & 8 \\
1998 & 20 & 5 low \\
1999 & 10 low & 5 low \\
2000 & 35 & 10.5 \\
2001 & $401^{\text {st }}$ peak & $\sim 10$ \\
2002 & 11 & 7 \\
2003 & 44 & 22 \\
2004 & $712^{\text {nd }}$ peak & $481^{\text {st }}$ peak \\
2005 & 56 & 32 \\
2006 & 58 & 40 \\
2007 & 50 & $742^{\text {nd }}$ peak \\
Total & $\$ 381 \mathrm{~b}$ & $\$ 238 \mathrm{~b}(63 \%$ of tankers $)$ \\
\hline
\end{tabular}

Source: Loyd's.

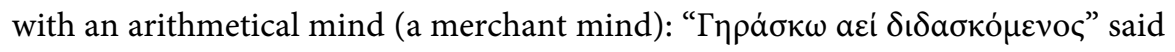
philosopher Socrates, meaning that "I become wiser as time goes-by, learning from facts". He learned the business of shipping, and especially of tankers, by himself or from Norwegians as it was written ${ }^{32}$.

\subsection{The End of Onassis' Life (March, 15 $\left.{ }^{\text {th }}, 1975\right)$}

His final fortune divided equally between Christina, his daughter, who passed away in 1988, and a "public benefit foundation" in memory of his son (who passed away in 1973, at 24). The foundation (1980) had to draw funds from the parallel business activity of 51 ships and 3 on order (1975). This caused O's companies to continue their activities for a longer future than his... This was the cleverest decision taken, we believe, which gave to his aides and their sons a job to continue and a task to benefit public.

\subsection{The Fleet after Onassis Death}

O's death caused his fleet to have a 20-year decadence till 1995 (Figure 6). This was something to be expected, when a strong manager used to take all decisions and risks by himself.

Despite this decadence the fleet re-assumed strength and surpassed its 1975 capacity by 2018 .

Let us see now a modern female shipowner.

\section{Part III: The case-study of Mrs. Angeliki N. Frangou}

\section{The Case-Study of an Amazing Female-Shipowner}

This case-study has a multiple interest as the shipowner is a married woman and

\footnotetext{
${ }^{32}$ Mpatis, E. (1999).
} 


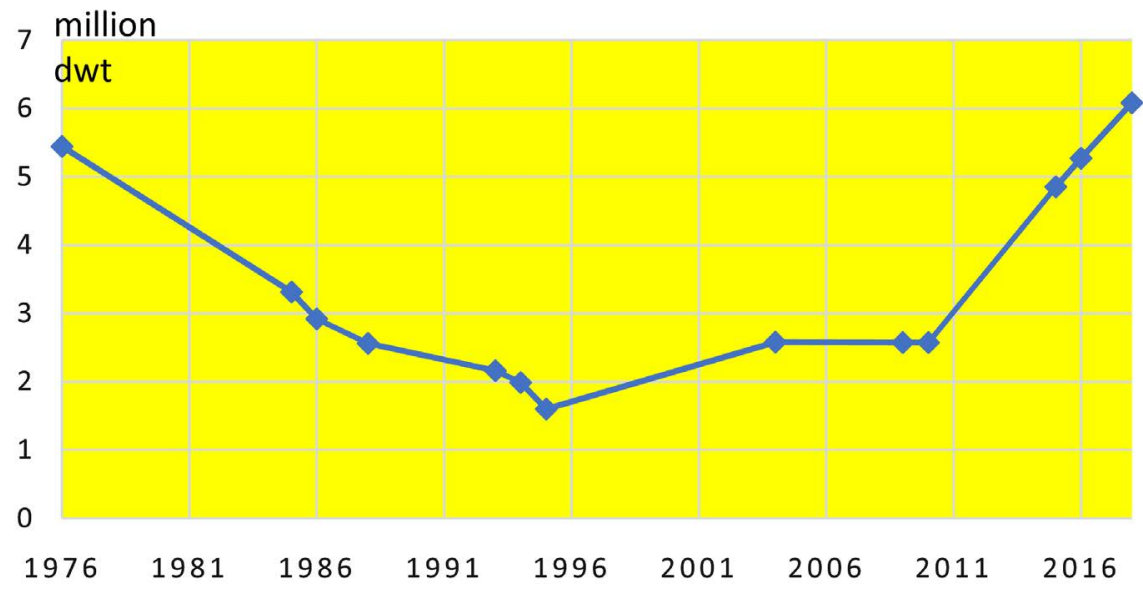

Figure 6. Onassis fleet, 1976-2018, selected years. Source: author, based on O's fleet statistics.

mother, and at the same time a modern top manager. Angeliki comes from a Greek traditional ship-owning family: the Frangos N. (Scan 3). She is born in Chios (Kardamyla). She overpassed, in fleet capacity, her father by leaps and bounds i.e., by more than 17 times (in...dwt) by 2018. Her father used to be a Captain, and a shipowner since 1966 in partnership ${ }^{33}$ with Moundreas $\mathrm{N}^{34}$. She argued (in June 2018) that maritime industry today is for Greece what wine-making is for France, Wall Street for New York and what is technology in Silicon Valley for USA; Shipping is part of Greek DNA.

As shown, Frangos N., father of Angeliki, is among the 43 traditional Greek shipowners, born in Chios, out of a total of 184 (23.4\%). Chian shipowners adding also those from Oinousai, arrive at 50 shipowners or $27 \%$ of total.

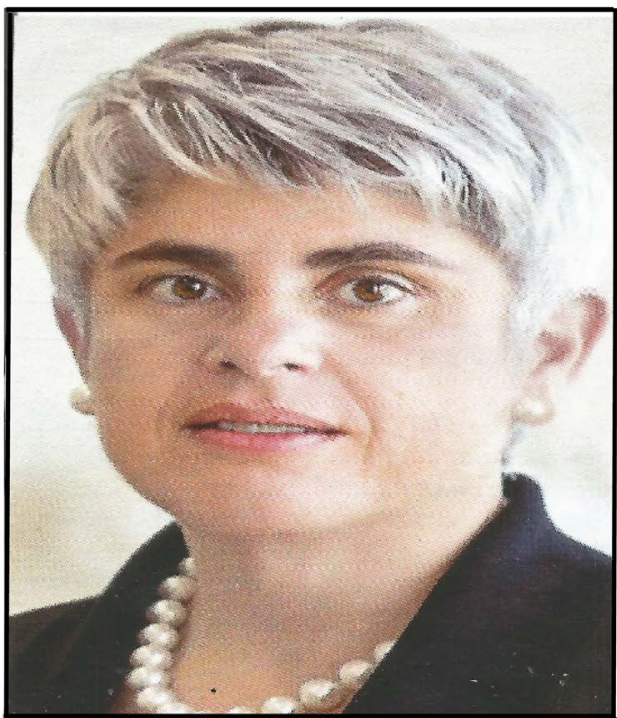

Angeliki, in charge of the "Navios Group", is a $5^{\text {th }}$ generation shipowner. Her grandfather was a partner of the father of $\mathrm{G} S$ Livanos. Her grandmother, and that of John Angelicoussis, were sisters. Chian shipping adopted successfully steam carriers in the distant past. Angeliki trained as an engineer, but she has hands-on and she knows vessels. Photo: used by permission.

${ }^{33}$ The father of Frangou established with N Moundreas the company "Good Faith" (1966). The company owned $1.07 \mathrm{~m}$ in 1991, held the $23^{\text {rd }}$ position in March $1994(1.14 \mathrm{~m} \mathrm{dwt})$ and the $49^{\text {th }}$ in end 2009 with $1.09 \mathrm{~m}$ dwt.

${ }^{34}$ In 2016, Moundreas N G alone owned $3.28 \mathrm{~m}$ dwt. 


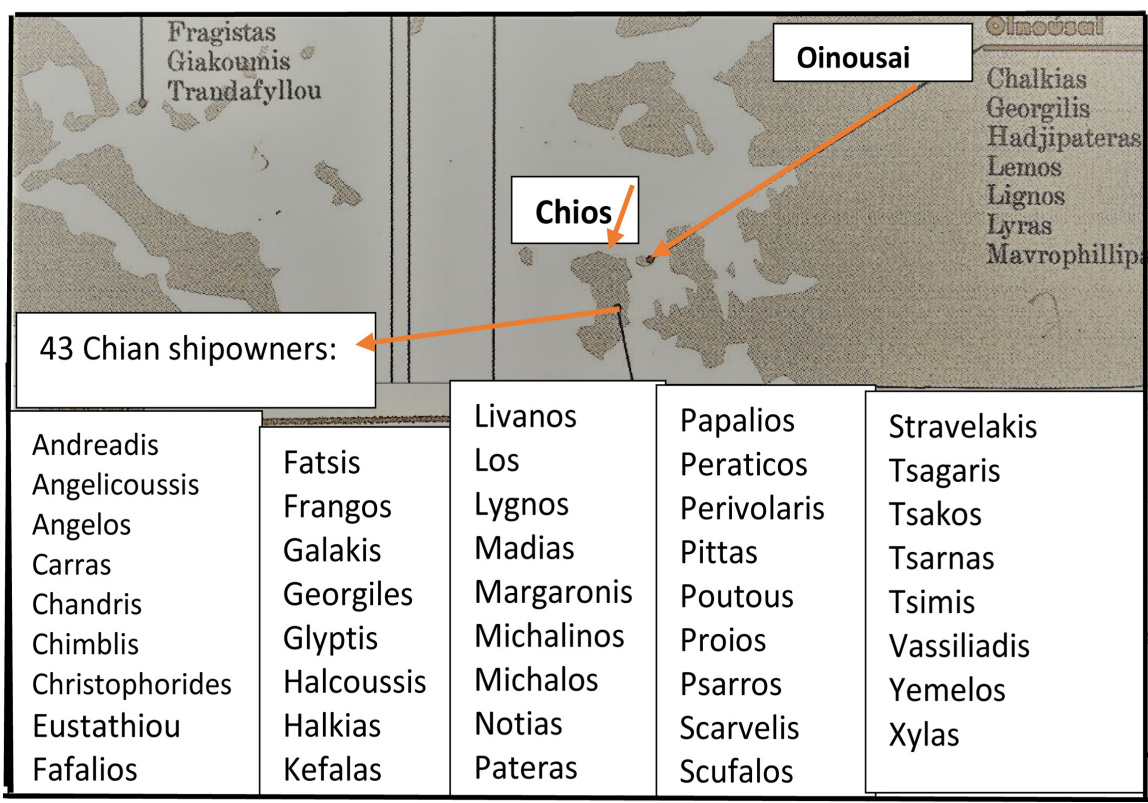

Scan 3. Chios: an island producing shipowners all along. Source: Surveyor magazine; undated; modified.

\subsection{The Navios Group}

Frangou, or Navios Group, (Graph 7), appeared in 1990 by founding the "Franser Shipping" company, and aimed at managing dry cargo ships, based in Piraeus.

The "Navios Maritime Partners" merged with ISE. "Navios" was a shipping company bought by Frangou in mid-2005. In 2010 it was estimated having a value of $\$ 3 \mathrm{~b}$. She also controls a company listed in London SE AIM named: "European Finance Investments". She is also in charge of the "Greek Information Technology" participating in Singular Logic. Moreover, she controls the Navios S America logistics Inc.

\subsection{The Group's Revenues and Profits}

Navios Maritime Holdings in 2008 had a revenue of \$1.3b against \$599 in 2009, as a result of the Global financial crisis. Profits were $\$ 118.5 \mathrm{~m}$ or $\sim 9 \%$ on revenue in 2008 and $\sim \$ 68 \mathrm{~m}$ in 2009 or $\sim 11 \%$. The crisis reduced by $43 \%$ the average daily time charter $(\$ 25,821$ agains $\$ 45,660)$ and the days in hire from 22,817 to 15,588 (or $-32 \%$ ). In 2010 the chartered-in vessels in 2010 earned $\$ 10,079 /$ day and the average time charter for core fleet varied from $\$ 28,313$ to $\$ 35,006$ per day.

\subsection{Frangou in Stock Exchange}

Angeliki knows-well the NY Stock Exchange as she used to work in Wall Street. She eventually led all her companies to NASDAQ. Greeks long absent from Stock Exchanges-SE- have derived \$1.5b in 2009. It is our intention to present, in a new work, the Greek shipowners listed in Stock Exchanges. 


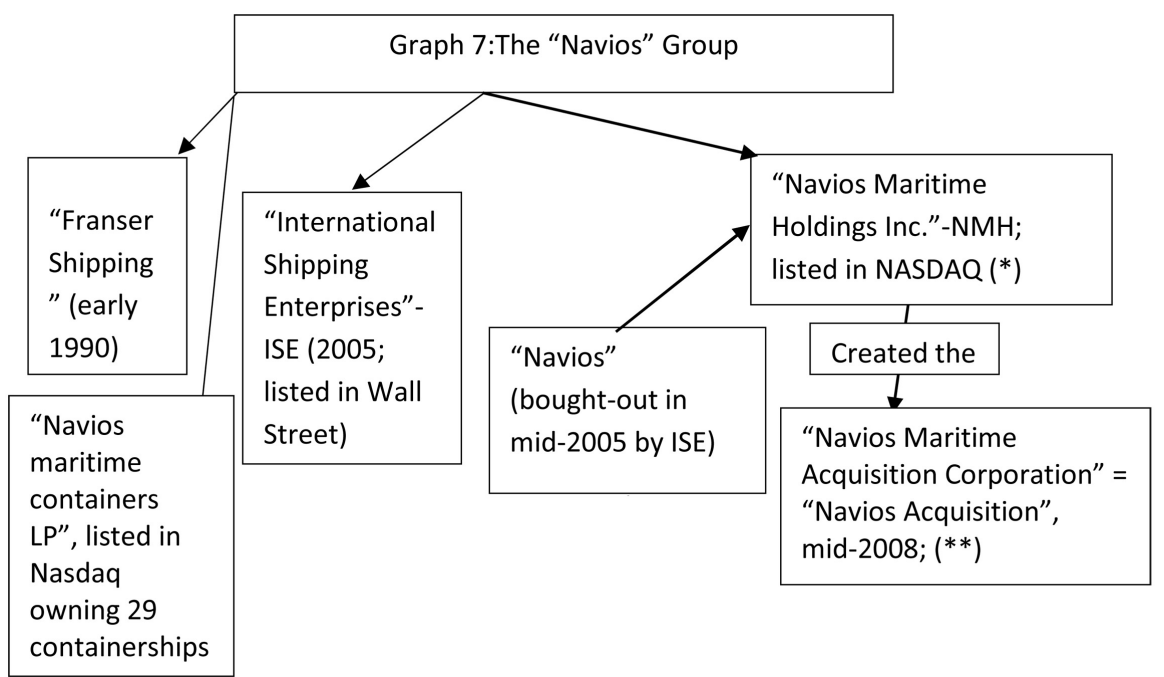

Graph 7. The "Navios" group. Source: author.

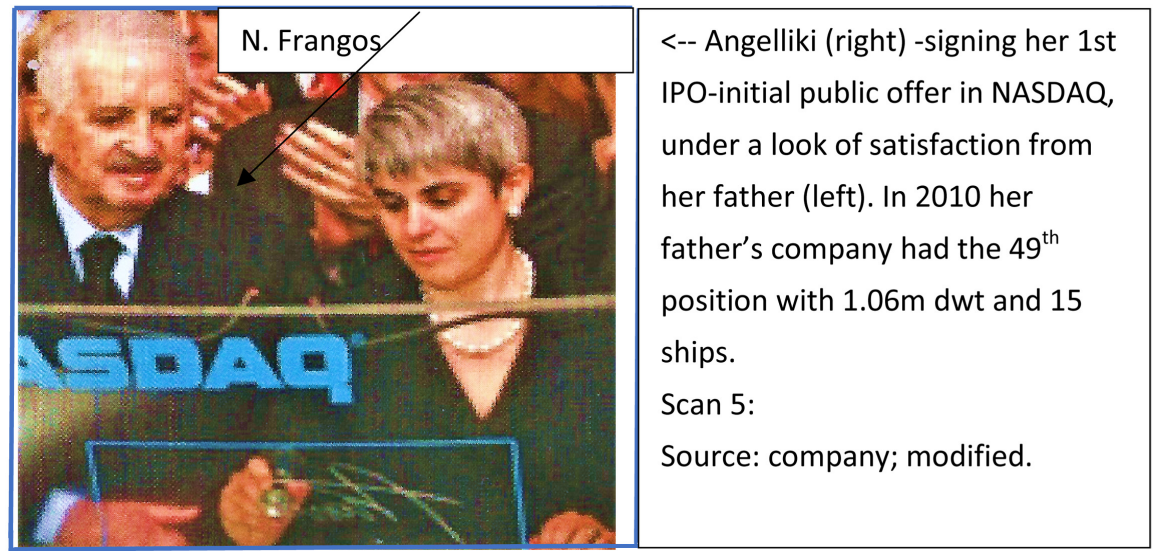

In 2005, she created, or rather re-vitalized the "blank checque" technique by creating the company "International Shipping Enterprises-ISE", listed subsequently in Wall Street. This was a sign of the confidence that Wall Street showed to Angeliki to list shares for an undisclosed in details shipping project! Investors knew amount and sector only. The Navios group listed in May $20083.5 \mathrm{~m}$ shares at $\$ 10.32(\$ 36.12 \mathrm{~m})$ in Nasdaq. In Sept. 2008 listed $2.8 \mathrm{~m}$ shares at $\$ 4.36$ (\$12.21m). In Nov. 2009 listed 4m shares at \$14.9 (\$59.6). In July 2018, Greeks had a $23 \%$ market share in Wall Street, by their capitalization of $\$ 6.3 \mathrm{~b}$ (March $31^{\text {st }}$ ), though the size of Greek companies was smaller than their competitors. There were 50 firms with a capitalization of $\$ 27.2 \mathrm{~b}$. Navios Maritime Partners held the last $10^{\text {th }}$ position with near $\$ 300 \mathrm{~m}$ capitalization in mid-2018.

\subsection{Frangou Faces the End-2008 Crisis}

Navios Maritime Holdings faced the maritime crisis as everybody else at the end of 2008 which halved its profits and revenue in 2009. In end-Jan. 2009 Frangou declared a "measured optimism" based on data about urbanization, construction contracts in China and in US in particular, and BDI (Figure 7). 


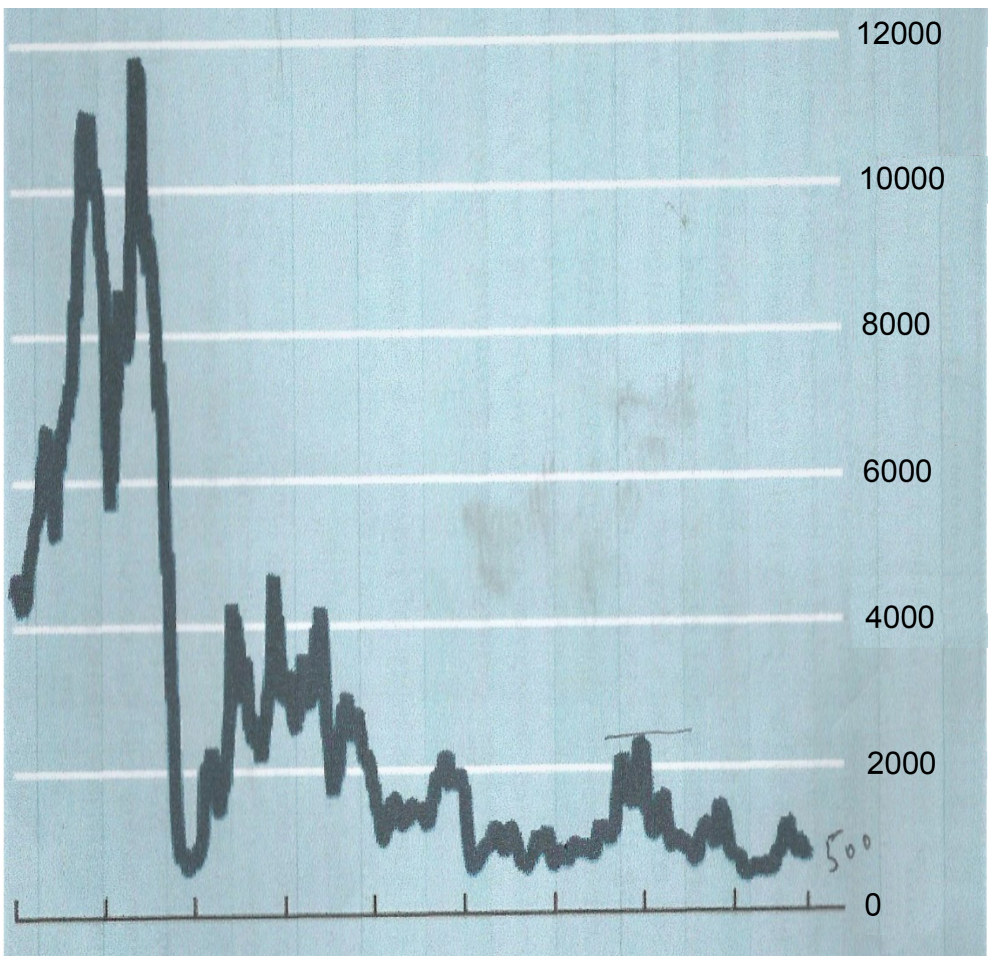

Figure 7. BDI-Baltic Drycargo Index, 2007-2016. Source: Thomson Reuters.

Navios Maritime Partners filed a shelf registration for up to $\$ 500 \mathrm{~m}$ for a credit facility. This action of Frangou meant to reduce a loan by $\$ 40 \mathrm{~m}$ (out of $\$ 235 \mathrm{~m}$ ) and saved $\$ 1.5 \mathrm{~m}$ of interest! Frangou apart from paying attention on interest cost, she paid attention also in the Yen/\$ parity and ordered 4 ships in Japan priced at $\$ 108 \mathrm{~m}$.

\subsection{The Investment Activity of Navios Group}

Her investments are shown in Table 7.

\subsection{Navios Final Growth}

"Navios" group final growth is as shown (Figure 8).

As shown, the growth of the "Navios" fleet is extraordinary. From 2008 to 2018 the fleet increased almost by 11 times, and this under a crisis!

\section{Concluding Remarks}

Onassis showed the way of how a fleet can become extra-large, and also, how this can be done fast. He made fleet's growth independent of its past profits, and based it on finance from other people's money. $\mathrm{O}$ understood that to become a shipowner was rather easy, but to find cargoes out there, was really a tough business. This try led him to the ill-fated S Arabian deal. $O$ said "that shipping was his wife". Onassis in fact had 4 wives: The super-Tankers. since 1938; Tina: since 1946; Maria: since 1959 and Jacky. since 1968.

Onassis and company's chief executives shared a desk in the same room. 
Table 7. Group's investments, 2009-2010.

\begin{tabular}{|c|c|c|c|c|}
\hline Company/Year & $\begin{array}{l}\text { Number of ships, } \\
\text { type, year built }\end{array}$ & Type, size (delivery in 2013) & Finance source & Remarks \\
\hline \multirow[t]{3}{*}{$\begin{array}{l}\text { "Navios Maritime } \\
\text { partners" }\end{array}$} & 2 new-buildings & $\begin{array}{l}\text {-Capesize } \\
\text {-Ultra-handymax, 61,000 dwt }\end{array}$ & $50 \%$ banking & \\
\hline & $\begin{array}{l}22^{\text {nd }} \text { hand } \\
\text { (b. } 2005 \text { \& } 6 \text { ) }\end{array}$ & $\begin{array}{l}\text {-Kamsarmax 82,790 dwt } \\
\text {-Panamax 76,619 }\end{array}$ & $50 \%$ banking & \\
\hline & 10 (b. after 2006) & $\begin{array}{l}5 \text { tankers } 30-80,000 \mathrm{dwt} \\
5 \text { containerships, } \\
2000-3400 \text { TEU }\end{array}$ & $\begin{array}{l}\text { Cash; banking } \\
\text { Cash }\end{array}$ & \\
\hline \multirow[t]{6}{*}{$\begin{array}{l}\text { "Navios Maritime } \\
\text { Acquisition", }\end{array}$} & $\begin{array}{l}22^{\text {nd }} \text { hand (b 2007) } \\
3 \text { new-buildings } \\
1 \text { eco tanker }\end{array}$ & $\begin{array}{l}\text { Tankers MR2s } \\
50,000 \mathrm{dwt}\end{array}$ & Cash & Low prices \\
\hline & 2 eco & MR2s; 2014 & & $\begin{array}{l}\text { Fleet of } 23 \text { crude carriers } \\
\& \text { product; } 11 \text { on order }\end{array}$ \\
\hline & 7 & $\begin{array}{l}158,000 \text { tons } \\
\text { ultra-handymax (Japan) }\end{array}$ & & $\begin{array}{l}\text { low prices; no one else } \\
\text { could buy }\end{array}$ \\
\hline & 42008 & & $\$ 324$ & 3 from a bank \\
\hline & $\begin{array}{l}7 \text { product carriers } \\
\text { new-buildings } \\
2 \text { chemical } 2010\end{array}$ & $\begin{array}{l}\text { MR 50,000 dwt 2012; } 225,000 \\
\text { dwt 2010; ordered by another } \\
\text { Greek shipowner }\end{array}$ & $\$ 457.7 \mathrm{~m}$ & $\begin{array}{l}\text { To enter tanker industry; } \\
\text { the group cultivated } \\
\text { good relations with } \\
\text { Commerzbank and S } \\
\text { Korea Shipbuilding }\end{array}$ \\
\hline & 2 tankers 2012 & $\begin{array}{l}\text { LR1 } \\
\text { LR1 }\end{array}$ & $\begin{array}{l}\$ 42.5 \mathrm{~m} \text { to be paid from ships } \\
\text { sold } \$ 40 \mathrm{~m} 2011 ; 440.5 ; \\
\text { pay } \$ 123 \mathrm{~m} \text { cash in installments } \\
\$ 334 \mathrm{~m} \text { from debt and } \\
\$ 60 \mathrm{~m} \text { from shares }\end{array}$ & Korea yard \\
\hline \multirow[t]{3}{*}{$\begin{array}{l}\text { Navios Maritime } \\
\text { Holdings }\end{array}$} & 7 new-buildings 2009 & Capes; 2010 & & $\begin{array}{l}\text { Secured cash flows for } \\
10 \text { years varied from } \\
\$ 247 \mathrm{~m}-303 \mathrm{~m} \text { for } \\
2010-13 \text {; lowest op. cost }\end{array}$ \\
\hline & $\begin{array}{l}2 \\
2009\end{array}$ & $\begin{array}{l}\text { Capes } 180,000 \mathrm{dwt} \text {; } \\
\text { 2010; from S Korea shipyard }\end{array}$ & $\begin{array}{l}\text {-Cash } \$ 141.5 \\
\text {-Mandatorily preferred stock at } \\
\$ 10 \text { conversion price; } \\
\text { Bank } \$ 75 \mathrm{~m}\left(^{*}\right)\end{array}$ & $\begin{array}{l}\text { Price reduced to } \\
\$ 115.6 \mathrm{~m} \text {; charter of } \\
10 \text { years }\end{array}$ \\
\hline & & & $\begin{array}{l}\$ 1.3 \mathrm{~b} \text { raised in cash; of which } \\
1 \mathrm{~b} \text { is from debt; } \$ 130 \mathrm{~m} \text { cash } \\
\text { from sales of ships to Navios } \\
\text { Mar. Partners }\end{array}$ & $\begin{array}{l}\text { Only } \$ 60 \mathrm{~m} \text { in debt ma- } \\
\text { turing in } 2010 \text { and }<130 \\
\mathrm{~m} \text { in } 2011\end{array}$ \\
\hline
\end{tabular}

Source: company's announcements. $\left(^{*}\right)$ A 10 -yearly loan at $1.75 \%$ over LIBOR, is rather an expensive one, ship's amortization estimated at 14 years at $\$ 29,356 /$ day hire.

Little, if anything, was kept secret from his closest aides. He had an esteem in management: "I do not need capital, he said, if I have good people around me, and good management; they will make money for me". "But even if you are the wealthiest man on earth, with bad management, you are going to lose even your own shirt' (italics added). The above, for the capital, is surely an exaggeration. 


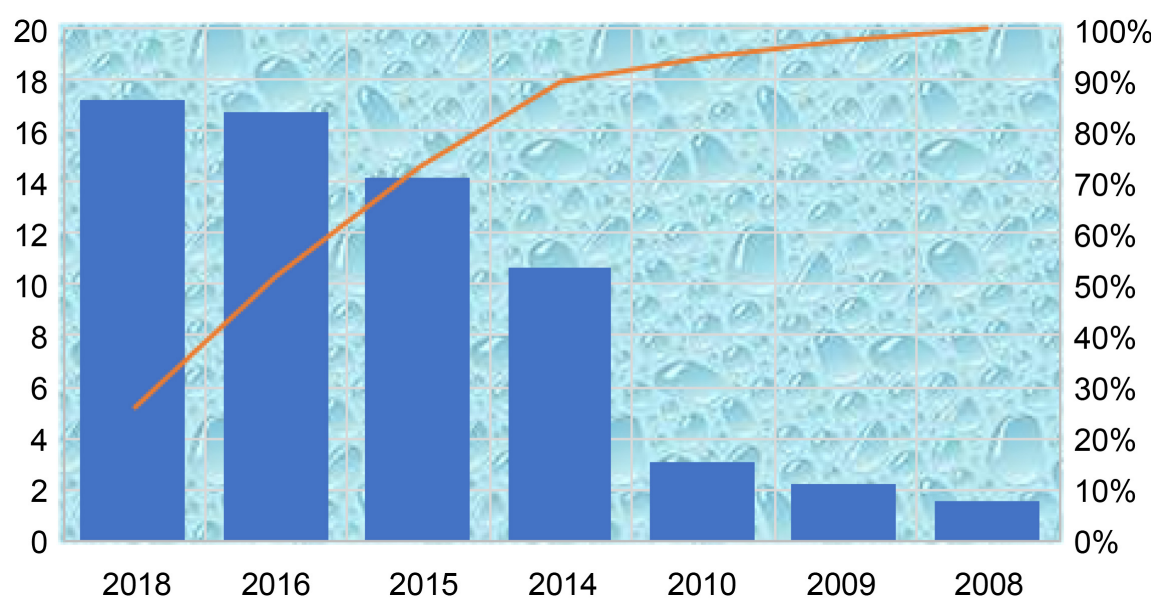

Figure 8. Navios' fleet evolution, 2008-2018. Source: author, with data from MIS-marine information services.

Capital is a necessary condition, but not a sufficient one.

Onassis had the affection and loyalty of his staff ( 250 persons). He looked in his staff mostly for loyalty as he said not for credentials, which as he said he could easily buy. Every company requested to keep detailed accounts, with proper directors' minutes. Junior managers were encouraged to share their ideas with him; he was after off-chances for a money-spinner in it, in all conversations. O could see if a person was telling lies or was a thief...

Shipping was quite rightly chosen by $\mathrm{O}$, as this was one industry to provide him the opportunity for exceptional wealth ${ }^{35}$. He was constantly after something new, and he was always active ${ }^{36}$. $\mathrm{O}$ was after tankers of higher quality and size than hitherto. It is easily recognized that $\mathrm{O}$ created a modern and powerful tanker fleet. O had the vision of big tankers, and his company at one point of time owned 22 VLCCs; ( $2 \mathrm{~m}$ barrels; over 200,000 dwt); he preferred the spot market and the relatively short-period- time charters.

He committed mistakes, as any human, because he let himself to be involved in a number of unfortunate projects ${ }^{37}$. The most important and painful of his failures, however, was as father. With a superstition to a lucky "star", O created a fortune, but he wished to be recognized primarily by his son... Onassis lacked the appreciation of his closest relatives, apart from his 3 sisters. During his youth displeased his family for wasting-away family's savings for freeing his imprisoned father...

O received love only from his grandmother Gethsemane- a religious woman. His mother Penelope passed away in 1912, whose married life lasted only 16 years. O was an orphan. His lucky "star", however, fell-down, when his only son,

\footnotetext{
${ }^{35}$ Though one member of the Laimos dynasty left in the 1980s, when he died, $£ 20 \mathrm{~b}$ !

${ }^{36} \mathrm{He}$ was against the idea to put his money in other people's business... as other shipowners have done with unpleasant results.

${ }^{37}$ Omega, Hampshire, Haiti, Scotland, Saudi Arabia, Monte Carlo \& Olympic Airways. We believe that $\$ 900 \mathrm{~m}$ at least lost in these projects. Preliminary research for a cost benefit analysis was apparently not used.
} 
and successor, died in an air crash. $\mathrm{O}$ was a person of no regrets and he never felt necessary to ask for forgiveness. When he harmed someone, by action or words, he used to send a proper gift as an excuse...Alexandros wanted his divorced mother back. For stubborn fathers, we believe, to love their son, it is required first for sons to show an absolute obedience to them. All hopes of Alexandros for his parents to re-unite disappeared when Tina married Niarchos (she passed away in 1974).

O did not obey ${ }^{38}$ to the traditional Greek shipowners' dogma. Traditional Greek shipowners told their children: "You have to live in such a way so that to pass unnoticed"! Greeks have the envy in their blood! Wealth etc. calls for the envy of the rest, since the ancient times of Iliad... In Iliad, Agamemnon, king of Mycenae, and commander-in-chief of the Greek expedition against Troy, deprived Achilles of his favorite slave-woman: Briseis...

O many times, sitting on the deck of his yacht "Christina", was staring for hours at sea watering his island. Onassis, metaphorically, was in fact a sailor by mentality-we believe- not an Odysseus or a citizen of mountain Olympus- looking every time at the distant horizon, ready to cross the sea for unknown lands meeting new people. From time to time, the sailor returns always to his Penelope-his official wife.

O always wanted to have a Penelope to wait for him at Scorpios' house, preparing...the "shroud" of her father-in-law. He was always returning to his island and kingdom... even for his last time for him to be buried there, under his island's soil and next to his son's tomb. Had $\mathrm{O}$ a coin to give to the ferryman "Charon"- a small shipowner in Greek mythology and...colleague of Onassisto pass his soul across river "Styx"? We believe that he, as a great shipowner, had a "free permit" to pass over to Hades' kingdom... This, however, was Onassis' ultimate and unique personal profit from his entire life on earth, which he only took with him in the Underworld!

Mrs. Frangou's competitive advantage is that she was aware, by her previous profession, of the best sources of cheap finance. "Navios Maritime Holdings" faced the last maritime crisis - as everybody else at the end of 2008, which halved its profit and revenue in 2009. In end-Jan. 2009 Frangou declared a "measured optimism" based on data about urbanization, construction contracts in China and in US in particular, and BDI (Baltic dry cargo index). Frangou's policy was to maximize the days of vessels under a time charter: $2010 / 90 \% ; 2011 / 66 \%$; $2012 / 57 \%$ and $2013 / 48 \%$, but the crisis made them falling. Frangou realized that to exploit a crisis one has to have cash, and be well capitalized and positioned, as she was.

\footnotetext{
${ }^{38} \mathrm{O}$ married the younger daughter Tina of Greek shipowner Stavros Livanos; he married the $1^{\text {st }} \mathrm{Op}$ era singer in the world; he also married the $1^{\text {st }}$ lady of USA. He became the $1^{\text {st }}$ tanker owner globally. He thus won... 4 Gold medals in shipping Olympic Games... and perhaps this explains why he chose as the name of his company and ships: "Olympic". "Olympus" mountain is the highest mountain in Greece of 2917 meters, alleged to be the home of the 12 mythical Gods, meaning a dazzling mountain due to Sun. O's ships had a dazzling white color...
} 
NM Partners filed a shelf registration for up to $\$ 500 \mathrm{~m}$ e.g., for a credit facility. This meant to reduce a loan by $\$ 40 \mathrm{~m}$ (out of $\$ 235 \mathrm{~m}$ ) and she saved $\$ 1.5 \mathrm{~m}$ of interest. Frangou paid attention also in the Yen/\$ parity and ordered 4 ships in Japan. Frangou held the idea that in a crisis unique opportunities are created, so that to buy ships at low prices. Frangou cancelled 12 shipbuildings, from an order of $\$ 265 \mathrm{~m}$, to stay liquid.

We may stress that the start of the investment rally of Frangou planned for 2009, in a crisis year. She looked for opportunities in the banks for failed loans and in shipbuilding yards for cancelled or distressed ships like in 2009. She could find cheap finance for this. In 2010 Frangou decided to enter into tankers.

\section{Conflicts of Interest}

The authors declare no conflicts of interest regarding the publication of this paper.

\section{References}

Bothwell, J. H. (1982). Will Greek Shipowners Flee the Flag? May. In Marine Engineering Log (pp. 145-146). New York: Simmons-Boardman Publishing Company.

Feroudi, K. (2011). The Onassis Women: The Way I Lived along with Them. Athens: Vima.

Forestie, F. (2009). Onassis, the Man Who Wanted All. Athens: Vima.

Goulielmos, A. M. (2020). Managing Shipping Companies, the Way Their Pioneers Did: The Case-Studies of Vafias N Family and Aristotelis S. Onassis. Modern Economy, 11, 2156-2182. https://doi.org/10.4236/me.2020.1112142

Harlaftis, G. (1993). Greek Shipowners \& Greece, 1945-1975: From Separate Development to Mutual Interdependence. London: The Athlone Press.

Kapsi, N. (2005). The Shipping Funds Invested in Greek Economy (Kerkyra ed.). Athens: Kerkyra.

Keynes, J. M. (1936). The General Theory of Employment, Interest and Money. London: Macmillan.

Koufopoulos, D. N., Lagoudis, I. N., Theotokas, I. N., \& Syriopoulos, T. C. (2010). Corporate Governance and Board Practices by Greek Shipping Management Companies. Corporate Governance, 10, 261-278. https://doi.org/10.1108/14720701011051901

Lorange, P., \& Fjeldstad, O. D. (2010). Redesigning Organizations for the 21st Century: Lessons from the Global Shipping Industry. Organizational Dynamics, 39, 184-193. https://doi.org/10.1016/j.orgdyn.2010.01.007

Lowry, N. (2003). Onassis and His Legacy, Published by "Informa/Lloyds List" for "Alexander S. Onassis Benefit Foundation”(p. 19). London.

Mpatis, E. (1999). Portraits in Blue Background: Persons that Wrote History in the $20^{\text {th }}$ Century Shipping. Piraeus: Finatec.

Randoy, T., Down, J., \& Jenssen, J. (2003). Corporate Governance and Board Effectiveness in Maritime Firms. Maritime Economics \& Logistics, 5, 40-54. https://doi.org/10.1057/palgrave.mel.9100059

Robbins, S. P., \& Coulter, M. (2018). With Contributions. Management (14th ed.). London: Pearson.

Stopford, M. (2009). Maritime Economics (3rd ed.). London: Routledge. https://doi.org/10.4324/9780203891742 